\title{
A Magyar Tudományos Akadémia Könyvtár és Információs Központ alapító állományának állattani témájú könyvei
}

\author{
SALLAI ÁGNES ${ }^{1 *}$ és SZABÓ ÁDÁM ${ }^{2}$ \\ ${ }^{1}$ Magyar Tudományos Akadémia Könyvtár és Információs Központ, Szakinformatikai Osztály, \\ 1051 Budapest, Arany János u. 1. *E-mail: sallai.agnes@konyvtar.mta.hu \\ ${ }^{2}$ Magyar Tudományos Akadémia Könyvtár és Információs Központ, Kézirattár és Régi Könyvek Gyüjteménye, \\ 1051 Budapest, MTA Palota, Széchenyi István tér 9. E-mail: szabo.adam@konyvtar.mta.hu
}

\begin{abstract}
Összefoglalás: Az MTA Könyvtár és Információs Központ alapító állományának összeállítása a magyar tudománytörténet talán legjelentősebb családjának, a TELEKIeknek köszönhető. A család három egymást követő generációja egy nagyjából harmincezer kötetet számláló gyüjteményt alakított ki Pesten, amelyet TELEKI József (1790-1855) ajánlott fel az 1825-27-es országgyülésen a frissen alapított Tudós Társaság számára, megvetve ezzel a Magyar Tudományos Akadémia könyvtárának alapjait. A bibliotéka természettudományos könyveinek feldolgozására korábban már több kutató is tett kísérletet, de a könyvállomány tételes feldolgozása, darabról darabra történő átvizsgálása csak nemrégiben történt meg. Ennek alapján közleményünkben az állattan témakörébe tartozó könyveket mutatjuk be.

Összesen 211 olyan mű (406 kötet) található az alapító állományban, amelyek témája egészben vagy részben állattani. Ennek ellenére mégis értékesnek mondható a gyüjtemény, ugyanis a TeLEKIek széles körü általános müveltséggel és kellően kiterjedt kapcsolati hálóval rendelkeztek ahhoz, hogy az európai kínálatból kiválasszák és megvásárolják a jelentős munkákat (amelyek a könyvpiacon más témákhoz képest csekélyebb számmal voltak jelen, mivel a zoológia tudománya ekkoriban még inkább csak kibontakozóban volt). A hazánkban kiadott, állattani témájú könyveket szinte teljes egészében beszerezték, a nemzetközi szakirodalomból pedig számos modernnek számító kiadvánnyal rendelkeztek olyan szerzők műveiből, akiket ma is az állattan történetének jeles alakjai között tartunk számon.
\end{abstract}

Kulcsszavak: TELEKI család, tudománytörténet

Elfogadva: 2019.09.26.

Elektronikusan megjelent: 2019.10.22.

\section{Bevezetés}

Jelen tanulmány célja a Magyar Tudományos Akadémia könyvtárának alapító állományába tartozó állattani témájú könyvek bemutatása. A gyüjtemény természettudományi könyveivel eddig csak két kutató foglalkozott: SOMKUTI 1966-ban és 1967-ben, két részre bontott tanulmányában SZÉCHÉNYI FERENC könyvtárának (az Országos Széchenyi Könyvár alapjául szolgáló gyüjteménynek) és a Teleki-állománynak a könyveit vette számba és vetette össze egymással (SOMKUTI 1966, 1967); CSANAK 1983- 
ban, a koronaőr TELEKI JÓZSEFről írt monográfiájában ismertette röviden az Akadémiai Könyvtár alapjául szolgáló pesti Teleki-könyvtár állományát, kitérve annak természettudományos részére is, továbbá 2001-ben a teljes alapító állomány kialakulásáról és tartalmáról írt (CSANAK 1983, 2001). A monográfia azonban értelemszerüen csak a könyvtár akkori állapotát vette figyelembe, a második munka pedig a gyüjtemény története mellett csupán vázlatosan szólt a könyvállomány összetételéről. SOMKUTI két tanulmánya kifejezetten a természettudományra koncentrált, a munka mindazonáltal nem hibátlan, mivel a Teleki-könyvtár egészéről nem állt rendelkezésre semmilyen lista vagy egyéb segédlet, amelyből kiindulva a teljesség igényével lehetett volna vizsgálni az állományt; így fordulhatott elö, hogy SOMKUTI tanulmánya több esetben olyan szerzők és müvek meglétét hiányolja, amelyek valójában részét képezték az állománynak, csak az általa használt (és az állománynak csupán egy részét tartalmazó) listán nem szerepelnek, például NICOLAUS JOSEPH VON JACQUIN, GEORGES CUVIER, RENÉ ANTOINE FERCHAULT DE RÉAUMUR munkái. Mára azonban megtörtént a Teleki-gyüjtemény alaposabb rekonstrukciója, így a teljes, mintegy harmincezer kötetnyire rúgó lista ismeretében immár nagyobb biztonsággal lehet megállapításokat tenni a TELEKIek állattani témájú könyvállományára vonatkozóan (SALlAI \& SZABÓ 2018).

\section{Módszerek}

A könyvlista összeállításánál kezdő időhatárként - a tudománytörténet álláspontjához igazodva - a 16. század közepét állapítottuk meg, amikor Európában a mai értelemben vett természettudományos szemlélet kezdte átvenni a természetismeret helyét (BAKONYI \& BAKONYI 2017), a végpontot pedig az 1863-as év jelenti, amikor a könyvtárba bekerülő könyveken utoljára tüntették fel a TELEKIekhez köthető eredetet. Az állomány túlnyomó többségét 18. századi kiadványok teszik ki, mivel a könyvtár összeállítása föleg erre az időszakra esett, a 19. században már kevesebb példánnyal gyarapodott; ennél korábbi, 16-17. századi müvek csak kis számban, kivételesen szerepelnek.

1. táblázat. A Magyar Tudományos Akadémia Könyvtár és Információs Központ Telekiállományában található állattani témájú könyvek megjelenési idő szerinti megoszlása.

Table 1. Zoological books in the Teleki collection of the Library and Information Centre of Hungarian Academy of Sciences according to date of publication.

\begin{tabular}{lc}
\hline Időszak & Múvek száma \\
\hline 16. sz. & 3 \\
17. sz. & 10 \\
18. sz.* & 165 \\
19. sz.* & 29 \\
s. a. & 5 \\
\hline Összesen & 212 \\
\hline
\end{tabular}

*Egy többkötetes sorozat a

18-19. sz. fordulóján lett kiadva. 
A nyelvi megoszlás is ehhez igazodik: a korszakban az addig hegemón szerepet játszó latin mellett előtérbe kerültek a nemzeti nyelvek, így a gyüjtemény korszerüségét valamint a német kultúra hazai müvelödésre gyakorolt befolyását - mutatja, hogy a német nyelvü könyvek vannak abszolút többségben; jóval kisebb a francia nyelvü kiadványok száma, magyarul írt munka pedig még kevesebb van, hiszen ekkoriban a hazai tudósok többsége még idegen nyelven fogalmazta meg a müveit.

2. táblázat. A Magyar Tudományos Akadémia Könyvtár és Információs Központ Telekiállományában található állattani témájú könyvek nyelvi megoszlása.

Table 2. Zoological books in the Teleki collection of the Library and Information Centre of Hungarian Academy of Sciences according to language.

\begin{tabular}{lcl}
\hline $\begin{array}{l}\text { Nyelvi } \\
\text { megoszlás }\end{array}$ & Múvek száma & Megjegyzés \\
\hline Német & 106 & \\
Latin & 60 & \\
Francia & 27 & az egyik francia-holland kétnyelvü kiadás \\
Magyar & 18 & \\
Angol & 1 & \\
Olasz & 1 & ebből kettő német-latin kétnyelvü kiadás \\
\hline Összesen & 213 & \\
\hline
\end{tabular}

Az ,állattan” témakörét tág határokon belül értelmeztük: nem csupán azokat a kiadványokat soroltuk ide, amelyek kifejezetten fajleírással, ökológiai megfigyelésekkel, a fajok evolúciójával foglalkoznak, hanem például a növénytani és állattani témájú részeket egyaránt tartalmazó sorozatokat, az őslénytani megfigyelésekről beszámoló munkákat, az állattenyésztési és állategészségügyi szakirodalmat, az iskolai tankönyveket, valamint a kompilációkat és a - gyakran saját megfigyelésekkel gazdagított - fordításokat is számba vettük. Ezen kérdéskörök ugyanis szervesen hozzátartoztak a könyvtár összeállítóinak, illetve olvasóinak az állatvilággal kapcsolatos tájékozódásához, amit az is mutat, hogy a korszakban elkészült szakrendi listákon a fenti csoportokba sorolható nyomtatványok mindegyike az állattan, illetve a természettudománynak megfelelő naturalis historia vagy physica nevü szakban található meg. Elsősorban tehát nem a modern állattan szempontjaira, hanem a könyvtár létrejöttének idején uralkodó müvelődési-tudományfelosztási viszonyokra voltunk tekintettel.

A tanulmány a fenti szempontok szerint tagolva mutatja be az egyes állományrészeket, kiemelve azok fontosabb jellegzetességeit, a tudománytörténetileg legmeghatározóbb szerzőket és müveket. A felépítést és a bemutatás rendjét illetően igyekeztünk BAKONYI \& BAKONYI (2017), a Pannonhalmi Főapátsági Könyvtár állattani témájú könyveiről szóló tanulmányát követni, amely tömörsége mellett is informatívan jellemzi a választott állományrészt; mindazonáltal tekintettel voltunk a különbségekre is, hiszen itt nem egy nagyon régi, nagymúltú, több évszázadon keresztül változatos módokon gyarapodó bibliotékáról van szó (BAKONYI \& BAKONYI 2016), hanem három olyan föúr könyvtáráról, akik nagyjából hetven éven át, személyes érdeklődésüknek és politikai-gazdasági-családi céljaiknak megfelelően, határozott koncepcióval folytattak könyvgyüjtést. 
Mivel mind a TELEKIek, mind az Akadémia első számú célja a hazai tudományosság vívmányainak összegyüjtése, megismertetése és a további fejlődés ösztönzése volt, erre való tekintettel minden témánál külön kiemeltük a legfontosabb magyar vonatkozású müveket, melyekröl részletesebben beszámoltunk a Magyar Könyvszemlében megjelent tanulmányunkban (SALLAI \& SZABÓ 2018). A könyvek listáját a tanulmány végén közöljük; ez az Akadémiai Könyvtár régi könyves állományának és az alapító gyüjteménnyel kapcsolatos kéziratos listáknak a tételes áttekintésén alapszik, így frissebb és teljesebb adatokat tartalmaz, mint az eddig megjelent kiadványok, illetve a könyvtár adatbázisa.

A listán külön jelöltük, hogy az adott mű rendelkezik-e az alapító állományhoz való tartozást egyértelműen jelző, 1836 és 1863 között használt Teleki-bélyegzővel. Számos olyan kiadványt is szerepeltetünk, amelyek nem rendelkeznek bélyeggel; ezeket a gyüjteményröl összeállított kéziratos listák, illetve a fizikai elhelyezkedésük alapján soroltuk be oda. Az esetükben feltételezhető, hogy a feldolgozásuk során elmaradt a bélyegző használata, vagy máshonnan is érkeztek példányok az adott könyvböl az Akadémiára, és az akkori könyvtárosok, fölöslegesnek ítélvén a többletet, a Teleki-példányt (talán rosszabb fizikai állapota miatt) eltávolították. Olyan eset is előfordul, hogy a kéziratos listán szereplö kiadvány a mai állományból teljesen hiányzik (az idők során elveszett vagy szándékosan kiselejtezték).

\section{Áttekintés és diszkusszió}

A TELEKIek a magyar tudománytörténet talán legjelentősebb fơúri családjának tekinthetőek; a család minden nemzedékében akadt valaki, aki maradandóan járult hozzá valamely diszciplína fejlődéséhez, akár saját tudományos munkája révén, akár mecénásitudományszervezői tevékenységgel, aminek a könyvgyüjtés és a könyvtáralapítás is a részét képezte. Voltak családtagok, akiknek érdeklődése kifejezetten a természettudományokra irányult. TELEKI SÁMUEL (1845-1916) például, aki RUDOLF trónörökös támogatásával világra szóló, sikeres expedíciót szervezett Afrikába (1886-1889), számos földrajzi, növénytani és állattani felfedezéssel gyarapította a tudományt (BALÁzS 1993). A ,zöld gróf” néven is emlegetett TELEKI GÉZA (1943-2014) szintén Afrikában végzett kutatásokat a föemlősök életét és viselkedését tanulmányozva, 1968-tól a közismert csimpánzkutató, JANE GOODALL munkatársaként müködött a Tanzánia nyugati részén található, Gombe Nemzeti Parkban. Jelentős természetvédelmi tevékenységet is folytatott, neki köszönhető az Outamba-Kilimi Nemzeti Park létrehozása Sierra Leonéban (SÁRKÖZY 2012).

Az Akadémiai Könyvtár alapító állományának kialakításában három TELEKI játszott fontos szerepet. Az akadémiai elnök nagyapja, a koronaőr JózSEF kezdte el a gyüjtemény kialakítását, pesti házában halálakor összesen 1723 mü volt található 3231 kötetben. Fia, LÁSZLÓ nagymértékben gyarapította az állományt, amely 1821-ben bekövetkezett halálakor mintegy huszonnégyezer kötetet számlált. Hagyatéka a tudományok iránt leginkább érdeklődő fia, JÓzSEF birtokába került, aki a következő években folytatta a könyvgyüjtést, és az 1826-os felajánláskor már harmincezer kötet tulajdonosa lehetett. 
A koronaör TELEKI JÓzSEF könyvtárában 19 mü (39 kötet) tárgyal az állattannal kapcsolatba hozható témákat. Vannak például a természettudománnyal általában foglalkozó leíró, rendszerező munkák, például a kor egyik legkiválóbb tudománynépszerüsítő szerzőjének számító BUFFON (1771-1774, 1774-1785, 1785) könyvsorozatának tizenöt darabja német nyelven, a növénytan és az állattan területén egyaránt maradandót alkotó svájci BONNET (1767, 1768, 1772, 1779-1781) értekezései; megvolt továbbá TELEKInek DECKER \& WEBER (1774-78) Naturgeschichte címü négykötetes összeállítása. Kifejezetten állatokkal foglalkozó könyv kevés van, azok is inkább állattenyésztési és állategészségügyi kérdéseket tárgyalnak. Úgy tünik, TELEKI JÓZSEF leginkább a juhtenyésztés iránt érdeklődött, ebből a témakörből négy mü is megtalálható az ő könyvtárának a darabjait tartalmazó katalógusokban. Természetesen magyar nemesként a lovakat sem hagyta figyelmen kívül, így a lótenyésztésről is szerzett be kiadványt. A korabeli gazdaságban fontos szerepet játszott a selyemhernyó-tenyésztés és a halászat, ezekről szintén egy-egy könyv szól. Szorosabb értelemben vett állattani témájú munkaként csak BUFFON (17701780, 1772-1777, 1785-1786) sorozatának néhány, külön tételként szereplő darabját lehet említeni, továbbá a 16. századi angol CAIUS (1729) latin nyelvű értekezéseit, amelyek egyike a britanniai kutyákról, a másik pedig az utazásai során látott ritka növény- és állatfajokról szól. A modern eszközök és módszerek iránti érdeklődést tükrözi NEEDHAM (1750) mikroszkóppal tett megfigyelésekről beszámoló kötete. A koronaőr JÓzSEF által összegyüjtött könyvtár - mint láttuk - annak halála után részben a fia, LÁSzLÓ tulajdonába került, LÁSZLÓ 1821-ben bekövetkezett halála után pedig az ő fia, a majdani akadémiai elnök, JÓZSEF vette át a könyvtár kezelését, aki az 1826-os felajánlás megtételéig, majd az 1844-es tényleges elszállításig tovább gyarapította azt, sőt a végrendeletében a saját személyes könyvgyüjteményét is az Akadémiai Könyvtárnak adományozta.

3. táblázat. A Magyar Tudományos Akadémia Könyvtár és Információs Központ Telekiállományában található állattani témájú könyvek téma szerinti megoszlása.

Table 3. Zoological books in the Teleki collection of the Library and Information Centre of Hungarian Academy of Sciences according to topics.

\begin{tabular}{lcc}
\hline Téma & Múvek száma & Kötetszám \\
\hline Állat & 78 & 161 \\
Vegyes & 53 & 142 \\
Gazdaság & 45 & 50 \\
Tankönyv & 27 & 41 \\
Őslénytan & 8 & 12 \\
\hline Összesen & 211 & 406 \\
\hline
\end{tabular}

A 16-18. századi, illetve még a 19. század elején munkálkodó tudósok is gyakran több tudományággal foglalkoztak, ezért gyakorta születtek olyan természettudományos témájú kiadványok, amelyek egyaránt tárgyalták a természetnek a korban számon tartott mindhárom nagy csoportját - „országát” - , a növényeket, az állatokat és az ásványokat; így az állattan szempontjából is célszerű az ilyen áttekintő jellegű munkákat megvizsgálni, hiszen aki a korszakban tájékozódni kívánt valamilyen állattani kérdésben, először az efféle kiadványokban nézett utána az adott témának. 
Ha a hazai vonatkozású (azaz magyarországi szerzőtől származó és/vagy a magyarországi élővilágról szóló) irodalmat nézzük, kijelenthető, hogy a TELEKIek széles körü gyüjtést végeztek, csaknem minden jelentős munkát beszerezve. APÁCZAI (1653) 17. századi enciklopédiája az első növény- és állattani szempontból egyaránt jelentős rendszerező mü, de megtalálható a gyüjteményben BÉL (1723), CSIBA (1714) és TURÓCZY (1729) 18. század eleji leírása is. KLEIN (1778) ritkaságokat bemutató müve szintén vegyes tartalmú, de állattani szempontból kiemelten érdekes, amennyiben részletesen ír a magyarországi kígyófajokról, külön fejezetet szentel a túzoknak, és a magyar szerzők közül elsőként említi a hosszúszarvú magyar juhot (KÁDÁR \& PRISZTER 1992). GÁTI (1792) természetrajza magyar nyelvüsége miatt számít fontosnak. Kiemelendő továbbá a pesti egyetemen tanító MITTERPACHER \& PILLER (1783) közös kiadványa, amely 1782-ben tett szerémségi kutatóútjukat mutatja be, az annak során felfedezett és leírt tudományra új növény- és állatfajokkal együtt; ebben a könyvben jelentek meg elöször hazai nyomdában készült, természethü növény- és állatábrázolások MITTERPACHER (1777-1794) másik fontos müve az Elementa rei rusticae, ami alapvetően agrártudományi tankönyv, de rendkívül sok növénytani és állattani ismeretanyagot közöl, a legújabb nemzetközi eredményeket is figyelembe véve.

A Teleki-könyvtár részét képezhették a következő három szerző könyvei, amelyekben azonban nem szerepel Teleki-bélyegző. Az első egy magyar jezsuita, ÉDER kuriózum jellegű müve, amelyet rendtársa, MAKÓ adott ki 1791-ben. ÉDER a mai Bolívia területén tevékenykedett misszionáriusként, és többek között a helyi flórával és faunával kapcsolatban tett megfigyeléseiről is beszámolt könyvében. Szintén csak közvetett bizonyítékok alapján tekinthető az állomány részének GROSSINGER (1793-97) ötkötetes munkája, amely az első kísérlet volt a teljes hazai flóra és fauna szisztematikus bemutatására.

A 18. század folyamán több külföldi utazó is megfordult Magyarországon, akik megfigyelték annak állat- és növényvilágát, illetve meglátogatták a különféle főpapi és fơuri természettudományos gyüjteményeket, majd könyv formájában számoltak be tapasztalataikról. Közéjük tartozott HoFFMANNSEGG (1800) gróf, akinek nyomtatásban megjelent levelei feltételezhetően megtalálhatóak voltak a TELEKIeknél. A feltételezést ezen három szerzőnél az indokolja, hogy könyveik még a 19. században felállított szakrendi részlegben találhatók, és mind előttük, mind utánuk Teleki-bélyegzővel ellátott müvek vannak a polcokon; a listákkal való összevetés alapján pedig számos ilyen esetben bebizonyosodott, hogy a kötetek rendszerezése során csupán hanyagságból maradt ki a Teleki-bélyegző az adott példányból.

A több tudományterülettel foglalkozó nemzetközi szakirodalomból ismét BUFFON-t lehet kiemelni, akinek a sorozatát újabb kiadásokban és több nyelven is beszerezték a koronaőr JÓZSEF utódai; bővítették továbbá a SCOPOLItól és BONNET-tól származó könyvek listáját; ezenkívül természettudományos témájú folyóiratokat is vásároltak (Der Naturforscher, Magazin der Naturkunde).

Egyfajta vegyes csoportot képeznek továbbá azok a természetrajzi munkák, leírások, amelyek elsősorban más tudományterületekre (főleg a növénytanra) koncentrálnak, de állattani kérdésekre is kitérnek. LIPPAY (1753) például a Posoni kert-ben megemlíti a vetemények kártevőit, tanácsokat adva az eltávolításukra, MÁTYUS (1787-1792) Diaeteticá-ja pedig a táplálkozással kapcsolatban közöl állattani vonatkozású 
információkat, valamint beszámol két sáskajárásról is; BENKÖ (1778) munkája Erdély jellegzetes állatainak leírását is magában foglalja.

Külön csoportként lehet kiemelni a Teleki-állományban szép számmal megtalálható, őslénytani megfigyelésekről beszámoló müveket, amelyek a legtöbbször alapvetően ásványtani témájúak. Magyar szempontból elsőként APÁCZAI-CSERE Jánost (1653) kell említeni, akinek müvében szerepel a fosszilizálódás folyamata; részletesebben először FRIDVALSZKY (1767) számolt be erdélyi mineralógiai müvében növények, kagylók, halak megkövült maradványairól; FICHTEL (1780) nevéhez pedig az erdélyi gerinctelen állatok első paleofaunisztikai összefoglalása füződik. Kifejezetten ösmaradványokkal foglalkozó mü pedig négy volt a Teleki-könyvtárban: a gyulafehérvári születésű BORN (1790) ismertetője az egyik tanítványa, ÉLÉONORE RAAB ősmaradvány-kollekciójáról, valamint az itáliai származású (de egy ideig Selmecbányán tanító) ScoPOLI (1769), a svájci tudományosság jelentős alakjának számító (Varsóban pedig miniszteri posztot is betöltő) BERTRAND (1763) és a német geológus-bányamérnök, több mineralógiai társaság névadója, WERNER (1785) egy-egy müve, amelyek átfogó jelleggel tárgyalják a kövületek jellegének és vizsgálatának kérdéseit.

A tényleges állattani témájú munkák közül a magyarországi állattan történetének legfontosabb szerzői és müvei - MISKOLCZItól PETÉNYIig - szinte kivétel nélkül megtalálhatók a Teleki-könyvtárban, néhány kutatónak még a munkásságát is támogatta egy vagy több családtag. A nemzetközi szakirodalomból is számos jeles természettudós munkáit gyüjtötték be. A 16. századi kezdeteket képviseli ALDROVANDI (1642) akinek állatokkal foglalkozó szép könyvei nemcsak tartalmuk, hanem megjelenésük, pontosabban a bennük található természethü képi ábrázolások miatt is komoly elörelépést jelentettek a modern zoológia kialakulása felé. A 17. században élt HARVEY (1680), aki a vérkeringéssel kapcsolatos megfigyeléseinek köszönhetően vált ismertté; itt az állatok szaporodásának és a szüznemzésnek a korszakban sokat vitatott témájával kapcsolatos eszmefuttatásainak gyűjteménye szerepel. A szintén 17. századi JoNSTONtól $(1650,1755,1756,1757)$ több összefoglaló mü is megtalálható volt a TELEKIeknél, bár a beszerzés idején már némileg idejétmúltnak számítottak ezek a müvek (SOMKUTI 1967). A LINNÉvel is kapcsolatban álló, de az állatok rendszerezésével LINNÉtől eltérően morfológiai alapon foglalkozó KLEINtől $(1750,1773)$ két müvet szereztek be, amelyek a tengeri állatokról és madarakról szólnak. Az összehasonlító anatómiában jelentős munkásságot kifejtő CUVIER-től (1817) az állatok országát feldolgozó négykötetes munka volt meg a könyvtárban. A természetrajz fejlődésére, elsősorban módszertanára nagy hatást gyakorló RÉAUMUR (1737-1741, 1749) szintén két müvével képviseltette magát a Teleki-állományban, köztük a főművének tekinthető Memoires pour servir a l'histoire de insectes címüvel (tíz kötetben). Hasonló témával foglalkozott BOERHAAVE (1758) több szerzőtárssal együtt megjelentetett egyik könyve, bár ő az orvostudomány történetében számít korszakalkotó tudósnak. Viszont az állattanban mondható nagy jelentőségünek a francia természetbúvár, LA CÉPÉDE (17881790) munkássága, akitől egy négykötetes, hüllőkkel foglalkozó müvet vásároltak meg a TELEKIek. LINNÉnek $(1773-1776,1789)$ a teljes természetrajzán kívül egy entomológiai tárgyú, Svédország rovarvilágát feldolgozó munkája található meg a gyüjteményben. Ki lehet emelni még a 18. század legjelentősebb ichtiológusai között számot tartott BLOCH (1782-1784, 1785-1791) összefoglaló munkáit, valamint BoNNET (1767, 1768, 1772, 1779-81) férgekkel, lepkékkel, egyéb rovarokkal és általában a szaporodás kérdésével 
foglalkozó műveit. A teljes lista azonban ennél jóval hosszabb: összességében 78 mü (161 kötet) található a TELEKIeknél, amelyek kifejezetten állattannal foglalkoznak, meglehetősen változatos megoszlásban. Vannak, amelyek bizonyos életjelenségeket vizsgálnak (mozgás, szaporodás, ösztönök stb.), mások egy adott terület faunájával foglalkoznak, a legtöbb pedig valamilyen állatcsoportot állít középpontba, közülük is a legnépszerübbek a rovartani, haltani és madártani témájú kiadványok.

Nem hiányoztak a Teleki-könyvtárból az oktatással kapcsolatos természetrajzi könyvek sem, amelyek magától értetődően az állattanra is kitérnek. Beszerzésük részben a család ifjabb generációinak kimüvelését célozhatta, egy-egy kiadvány megjelenési éve esetleg arra is következtetni enged, hogy melyik apa vette melyik fiának (EBERT 1776-77-es és MITTERPACHER 1777-79-es könyveit például az idősebb JÓZSEF LÁSZLÓnak, GLATZ és SZENTGYÖRGYI 1803-as mủveit pedig valószínüleg LÁSZLÓ az ifjabbik JÓZSEFnek). Ezenkívül mindegyik TELEKI aktívan foglalkozott az iskolaüggyel: a koronaőr JÓzSEF pécsi tankerületi főigazgató volt, LÁSzLÓt a kolozsvári református kollégium gondnokává választották és saját müvet is írt a nevelésröl, az ifjabb JÓZSEF pedig a sárospataki kollégium főgondnoki tisztségét töltötte be. A tankönyvek vásárlása tehát mind a gyermekeik nevelését, mind az oktatásügyben való általános tájékozódást elősegítette.

Nagy hangsúlyt fektettek a hazai flórát és faunát megismertető müvek gyüjtésére. A legkorábbi darab a Ratio educationis-ban lefektetett elveket tükröző egyik első disszertáció, KERESZTÚRI, TICHY és REIFF közös munkája (KERESZTÚRI et al. 1779). A korszak elsö számú természetrajzi tankönyvírója viszont a már említett MITTERPACHER (1777-94) volt, akinek több írását is beszerezték. Kifejezetten állattani témájú SEVERINI (1779) munkája, amelyben egy saját állatrendszertan bevezetésére tett kísérletet. Egy másik, metszetekkel ellátott tankönyv, a debreceni SZENTGYÖRGYIé (1803), szintén az állatok országát mutatta be, egy egész természetrajzra kiterjedő sorozat első részeként, a folytatása azonban nem készült el. Számos külföldi, elsősorban német nyelvü tankönyvből is tanulhattak a TELEKI gyermekek, például a neves wittenbergi természettudós, EBERT (1776-1777) vagy az orvostudományban is jelentősnek számító KRÜGER (1748-1750, 1753, 1771, 1774) müveiből. Kiemelhető továbbá BERTUCH (1807-1808) színes metszetekkel ellátott természetrajzi könyvsorozata, amelynek 19. század eleji, bécsi kiadását latin és magyar fordítással is ellátták.

A TELEKIek a természettudományok elméleti müvelése mellett nagy hangsúlyt fektettek azok gyakorlati hasznosítására is. Az alapító állományt kialakító mindhárom családtag végzett hosszabb külföldi tanulmányokat, amely során egyrészt megtapasztalták Magyarország gazdasági elmaradottságát a fejlettebb nyugat-európai országokhoz képest, másrészt ennek a hátránynak a ledolgozása érdekében gondosan tanulmányozták az ott alkalmazott módszereket és eszközöket. Általános hazafiúi érzületük mellett természetesen személyes érdekük is füződött a legújabb technikai és gazdasági vívmányok megfigyeléséhez, hiszen nagybirtokos arisztokratákként a saját jövedelmeik növeléséhez is elengedhetetlen volt számukra a földjeiken folyó termelőmunka versenyképességének, korszerüségének biztosítása. Mindez az állatokkal kapcsolatos kérdéseket is érintett: az egyes állatfajták tenyésztése, egészségük megóvása, gazdasági hasznosításuk lehetőségei úgyszólván nélkülözhetetlen részét képezték minden TELEKI gróf ismeretanyagának. Mindezen szempontok véleményünk szerint elegendő indokot jelentenek ahhoz, hogy az alapító állomány állattani témájú könyvei között a háziállatokkal foglalkozó különféle 
kiadványokat is tárgyaljuk, hiszen a gyüjtemény összeállítói számára ezek a művek tulajdonképpen a korábban felsorolt munkák révén elsajátított tudás gyakorlati oldalát jelentették.

A gazdasági témájú müvek jelentőségét a számuk is mutatja. A koronaőr TELEKI JózSEF állatokkal kapcsolatos könyvállományának például több mint egyharmadát az ide sorolható kiadványok teszik ki, fia és unokája pedig mintegy negyven ilyen munkát szerzett be, magyar és külföldi vonatkozásúakat egyaránt. Van köztük a mezőgazdasági kérdésekkel általában foglalkozó értekezés is (PETHE 1805, TESSEDIK 1786), de a többségük egy-egy állatcsoportra vagy témára koncentrál. Kiemelten érdeklődtek például a lovak tenyésztése és idomítása iránt (CAVENDISH 1729, CSEKONICS 1817, HIVER 1783 stb.), hiszen mezőgazdasági, hadászati és közlekedési szempontból, továbbá az általuk biztosított társadalmi presztízs miatt ezek az állatok számítottak a legértékesebbnek a korban. Több méhészeti témájú könyvet vásárolt a két ifjabb TELEKI (CHRIST 1783, EYRICH 1774, JANSCHA 1790, HANDERLA 1810, RIEM 1775, SZIGETI 1763); ez a mezőgazdasági ágazat szintén nagy népszerüségnek örvendett, és komoly hagyományokkal rendelkezett. Újonnan fellendülő iparág volt a textilgyártás, amely a juhtenyésztési szakkönyvek (KLOBB 1790, LOSSIUS 1791) beszerzését indokolta; illetve ehhez a területhez kapcsolódott a selyemhernyó-tenyésztéssel foglalkozó irodalom is (Hinlängliche Anleitung... 1767). A szarvasmarha-, sertés- és baromfitartás kérdéseit csak egy-két könyv tárgyalta az alapító állományban (BERGEN, 1800, BUCHOZ 1785, HÖCK, 1792, TAM 1764), illetve megtalálható volt még egy galambokkal foglalkozó mü is (Gründlicher Unterricht in der Taubenzucht 1798). Több kiadvány foglalkozott a haszonállatok egészségügyi ellátásával, akár általánosságban, akár egy bizonyos fajtára vagy betegségre fókuszálva (CARENO 1801, ROHLWES 1814, Pferdearzt 1752, TOLNAY 1816). Végül kuriózumként említendő a jeles történész, PRAY (1749) jezsuita szerző latin nyelvü solymászati tankölteménye, amely elsősorban poétikai célokat követ, de számos helyes megállapítást is tesz ezen ragadozó madarak nevelésére és a velük folytatott vadászatra vonatkozóan.

\section{Összegzés}

Az Akadémiai Könyvtár alapító állományában a teljes mennyiséghez képest az állattani témájú müvek csak kis számban fordultak elő; arányuk még úgy is meglehetősen csekélynek mondható, ha tágabb értelmezéssel a vegyes tartalmú, illetve inkább (mező)gazdasági szempontokra koncentráló munkákat is ide számítjuk. A harmicezres bibliotékában mindössze 406 állattani vonatkozású kötet volt megtalálható; ezekböl 47 olyan mủvet lehet kiválogatni, amelyek valamilyen módon magyar kötődésűek. Csekély számuk mindazonáltal nem annyira az alapítók érdeklődésének hiányát, mint inkább a korabeli viszonyokat tükrözi. A 18. században és a 19. század elején a természettudományok fellendülöben voltak ugyan, de a modern időkben élvezett fontosságukat még meg sem közelítették; Magyarország sajátos politikai-közjogi helyzete miatt pedig idehaza más diszciplínák álltak az érdeklődés homlokterében. Ennek figyelembe vételével a TELEKIek könyvgyüjtő munkája elismerést érdemel, hiszen a hazánkban kiadott, témánkba illö könyveket szinte teljes egészében beszerezték, és a 
nemzetközi szakirodalomból is számos modernnek számító kiadvánnyal rendelkeztek, olyan szerzők tollából, akiket ma is az állattan történetének jeles alakjai között tartanak számon.

Köszönetnyilvánítás. Köszönjük Dr. BAKONYI GÁBOR és Dr. VIG KÁROLY alapos, nagy segítséget nyújtó lektori munkáját.

\section{Irodalomjegyzék}

Aldrovandi, U. (1642): De reliquis animalibus exanguibus. Bologna, Ferronii, 593 pp.

APÁCZAi CsERE, J. (1653): Magyar encyclopaedia. Utrecht, Waesberge, 487 pp.

BAKONYI, G. \& BAKONYI, Zs. (2016): A Pannonhalmi Főapátsági Könyvtár zoológiai könyvei a 1618. századból. Magyar Könyvszemle 132(4): 463-478.

BAKONYI, G. \& BAKONYI, Zs. (2017): A Pannonhalmi Főapátsági Könyvtár kora újkori zoológia könyveinek vizsgálata. Állattani Közlemények 102(1-2): 3-23. https://doi.org/10.20331/AllKoz.2017.102.1-2.3

BALÁzs, D. (ed.) (1993): Magyar Utazók Lexikona, Panoráma, Budapest, 464 pp.

BÉL, M. (1723): Hungariae antiquae et novae prodromus. Nürnberg, Monath, 204 pp.

BENKö, J. (1778): Transsilvania, sive magnus Transsilvaniae Principatus, olim Dacia Mediterranea dictus. orbi nondum satis cognitus. nunc multifariam, at strictim illustratus. Bécs, Kurzböck, 2 köt.

BERGEN, J. C. (1810): Anleitung zur Viehzucht oder vielmehr zum Futtergewächsbau und zur Stallfütterung des Rindviehes. Berlin, Realschulbuchhandlung, 482. pp.

BERTRAND, É. (1763): Dictionnaire universel des Fossiles propres et des Fossiles accidentels, contenant une description des terres, des sables, des sels, des soufres, des bitumes, des pierres simples \& composées, etc. Hága, Grosse - Pinel, 606 pp. https://doi.org/10.5962/bhl.title.145196

BeRTUCH, F. J. (1807-1808): Novus orbis pictus juventuti instituendae et oblectandae. Bécs, Pichler, 4 köt.

Bloch, M. E. (1782-1784): Oeconomische Naturgeschichte der Fische Deutschlands. Berlin, Hesse Buchhandlung der Realschule, 3 köt. https://doi.org/10.5962/bhl.title.105191

BLoch, M. E. (1785-1791): Oeconomische Naturgeschichte der ausländischen Fische, Berlin, Buchhandlung der Realschule - Morino \& Comp., 5 köt.

BoerhaAve, H., Flloyd, T., Hill, J. \& Swammerdam, J. (1758): The Book of Nature; or, the History of Insects. London, Seyffert, $472 \mathrm{pp}$.

BonNET, C. (1767): Contemplation de la nature, Yverdon, s. n., 2 köt.

Bonnet, C. (1768): Considérations sur les corps organisés. Amszterdam, Rey, 580 pp.

BonNET, C. (1772): Betrachtungen über die Natur. Lipcse, Junius, 675 pp.

Bonnet, C. (1779-1781): Oeuvres d'histoire naturelle et de philosophie de Charles Bonnet. Neuchatel, Fauche, 7 köt. https://doi.org/10.5962/bhl.title.51265

Born, I. (1790): Catalogue méthodique et raisonné de la collection des fossiles de Mlle Éléonore de Raab. Bécs, Degen,. 4 köt. 
BuchOz, P. J. (1785): Oekonomisch-physikalische Abhandlung vom Federvieh. Bécs, Trattner, 288 pp.

Buffon, G. L. L. (1770-1780): Histoire naturelle des oiseaux. Párizs, Impr. Royale, 14 köt. https://doi.org/10.5962/bhl.title.66490

Buffon, G. L. L. (1771-1774): Allgemeine Naturgeschichte. Berlin, Pauli, 7 köt.

Buffon, G. L. L. (1772-1777): Naturgeschichte der Vögel. Berlin, Pauli, 6 köt.

Buffon, G. L. L. (1774-1785): Oeuvres complètes: histoire naturelle, générale et particulière. Párizs, Impr. Royale, 43 köt. https://doi.org/10.5962/bhl.title.156847

Buffon, G. L. L. (1785-1786): Naturgeschichte der vierfüssigen Thiere. Troppau, s. n., 2 köt.

CaIUs, J. (1729): De canibus Britannicis, lib. 1.: De rariorum animalium et stirpium historia, lib. 1. De libris propriis, lib. 1. De pronunciatione Graecae et Latinae linguae. London, Davis, 271 pp.

CAREnO, L. (1801): Ueber die Kuhpocken: eine Volksschrift. Bécs, Camesina, 40 pp.

CAVENDish, W. (1729): Die neueste Lehr-Art und besondere Erfindung die Pferde zu dressiren, oder abzurichten und zu arbeiten, und zwar nach der Natur, welche durch subtile Kunst-Griffe zur Vollkommenheit gebracht wird. Nürnberg, Lochner, 470 pp.

Christ, J. L. (1783): Anweisung zur nützlichsten und angenehmsten Bienenzucht. Frankfurt - Lipcse, Fleischer, $416 \mathrm{pp}$.

Cuvier, G. (1817): Le régne animal. Párizs, Deterville, 4 köt.

CsAnAK, D. (1983): Két korszak határán. Akadémiai Kiadó, Budapest, 492 pp.

CsANAK, D. (2001): A Telekiek gyüjteménye. In: FeKETE, G.-né (eds): Örökségünk, élő múltunk: Gyüjtemények a Magyar Tudományos Akadémia Könyvtárában. A Magyar Tudományos Akadémia Könyvtárának közleményei (37/112). Magyar Tudományos Akadémia Könyvtára, Budapest, pp. 11-33.

Csekonics, J. (1817): Praktische Grundsätze die Pferdezucht betreffend. Pest, s. n., 250 pp.

CsibA, M. I. (1714): Dissertatio historico-physica de montibus Hungariae. Nagyszombat, Typis Academicis, $149 \mathrm{pp}$.

DeCKeR, J. M. (1774-1778): Naturgeschichte aus den besten Schriftstellern mit Merianischen und neuen Kupfern. Heilbronn, Eckebrechtische, 4 köt.

EBERT, J. J. (1776-1777): Naturlehre für die Jugend. Lipcse, Weidmann, 3 köt.

ÉDER, X. F. (1791): Descriptio provinciae Moxitarum in regno Peruano quam e scriptis posthumis Franz Xav. Eder e Soc. Jesu annis XV. sacri apud eosdem curionis digessit, expolivit, et adnotatiunculis illustravit abb. et consil. reg. Mako. Buda, Typis Universitatis, $401 \mathrm{pp}$.

EYRICH, J. L. (1774): Gesammelte und nach Vernunft und Erfahrung geprüfte Nachrichten von der Winterung der Bienen. Nürnberg, Zeh, 110 pp.

FICHTEL, J. E. von (1780): Beytrag zur Mineralgeschichte von Siebenbürgen. Nürnberg, Verlag der Raspischen Buchhandlung, 158 pp.

FRIDVALSZKY, J. (1767): Mineralogia magni principatus Transsylvaniae. Kolozsvár, Typis Academicis Societatis Iesu, $220 \mathrm{pp}$.

GÁTI, I. (1792): A természet históriája. Máramarossziget, s. n., 32 pp.

GAZDA, I. (2013): Magyar tudománytörténet. A reáltudományok területén magyar kutatók által 1945 elött elért kiemelkedö eredményekböl. Történeti összefoglalók, bibliográfiák. A Magyar Tudománytörténeti Intézet tudományos közleményei, 118. Magyar Tudománytörténeti Intézet, Budapest, $219 \mathrm{pp}$.

GÉCZY, B. (1995): A magyarországi öslénytan története. Akadémiai Kiadó, Budapest, 74 pp. 
GLATZ, J. (1803): Naturhistorisches Bilder- und Lese-Buch. Reutlingen, Mäck, 360 pp.

Grossinger, J. (1793-1797): Universa Historia Physica regni Hungariae secundum tria regna naturae digesta. Pozsony, Weber, 5 köt.

HanÁk, J. (1849): Az állattan története és irodalma Magyarországon. Kiadta Pólya József. Pesten, $220 \mathrm{pp}$.

HANDERLA, Gy. (1810): Új méhész, vagy-is a méheknek magyar hazánkhoz alkalmaztatott gondviselése. Pozsony, Weber, $182 \mathrm{pp}$.

HARVEY, W. (1680): Exercitationes de generatione animalium. Hága, Leers, 622 pp.

Hiver, J. (1783): Englische Zucht und Behandlung der Pferde. Bécs, Wappler, 111 pp.

HoffMANNSEGG, J. C. (1800): Reise des Grafen von Hofmannsegg in einige Gegenden von Ungarn bis an die türkische Gränze : ein Auszug aus einer Sammlung von original Briefen. Görlitz, Anton, $255 \mathrm{pp}$.

HöcK, J. D. A. (1792): Oekonomische Abhandlung von der Schweinszucht. Frankfurt, Jäger, 38 pp.

JANSCHA, A. (1790): Hinterlassene vollständige Lehre von der Bienenzucht. Bécs, Kurzbeck, 222, pp.

Jonston, J. (1650): Historiae naturalis de avibus libri VI. Frankfurt - Lipcse, Merian, 227 pp.

Jonston, J. (1755): Theatrum universale omnium animalium quadrupedum. Heilbronn, Eckebrecht, $244 \mathrm{pp}$.

Jonston, J. (1756): Ioannis Ionstoni theatrum universale de avibus. Heilbronn, Lannoy, 256 pp.

Jonston, J. (1757): Historiae naturalis de serpentibus libri duo. Heilbronn, Eckebrecht, 58 pp.

KÁDÁR, Z. \& PRISZTER, Sz. (1992): Az élővilág megismerésének kezdetei hazánkban. Akadémiai Kiadó, Budapest, 134 pp.

KeRESZTÚRI, J., REIFF, J. I. \& TICHY, I. (1779): Tentamen publicum ex regno animali quod in regia universitate Budensi anno 1779 subibunt. Buda, Typis Regiae Universitatis, 46 pp.

KLEIN, J. T. (1750): Historiae avium prodromus. Schmidt, Lübeck, 254 pp.

KLEIN, J. T. (1773): Descriptiones tubulorum marinorum. Danzig \& Lipcse, Gleditsch, 44 pp.

KLobB, H. E. (1790): Abhandlung von den Hauptkrankheiten und Verhalten der Schaafe. Regensburg, Montag, 77 pp.

KRÜGER, J. G. (1748-1750): Naturlehre (II-III.). Halle, Hemmerde, 2 köt.

KRÜGER, J. G. (1771): Naturlehre, nebst Kupfern und vollständigen Register. Halle, Hemmerde, 943 pp.

KRÜGER, J. G. (1774): Elementa philosophiae naturalis. Kolozsvár, Colleg. Ref., 430 pp.

KRÜGER, J. G. (1753): Philosophia naturalis experimentis confirmata. Halle, Hammerde, 1070 pp.

LA CÉPÈDE, B.-G. É. (1788-1790): Histoire naturelle des quadrupèdes ovipares et des serpens. Párizs, Hotel de Thou, 4 köt. https://doi.org/10.5962/bhl.title.5036

LINNÉ, C. (1773-1776): Vollständiges Natursystem. Nürnberg, Raspe, 9 köt.

LinNÉ, C. (1789): Entomologia, Faunae Suecicae descriptionibus aucta. Lyon, Delamollier, 4 köt.

LipPAY, J. (1753): Posoni kert. Győr, Streibig, 698 pp.

Lossius, F. D. (1791): Die beste und natürlichste Behandlung der Schaafe dieselben vor allerlei bösartigen Zufällen zu verwahren und die Schäfereien in Aufnahme zu bringen. Lipcse, Böhme, $286 \mathrm{pp}$.

MÁTYUs, I. (1787-1792): Ó és új diaetetica az az, Az életnek és egésségnek fenn-tartására és gyámolgatására Istentöl adattatott nevezetesebb természeti eszközöknek a szerint való elé- 
számlázása a mint azokra reá kaptak, és eleitöl fogva min ez ideig magok károkra vagy hasznokra vélek éltek az emberek. Pozsony, Landerer, 5 köt.

MitTERPACHER, L. (1777-1794): Elementa rei rusticae in usum academiarum regni Hungariae. Buda, Typis Regiae Universitatis, 3 köt.

MITTERPACHER, L. (1777-1779): Elementa rei rusticae in usum academiarum regni Hungariae (I-II). Buda, Typis Regiae Universitatis, 2 köt.

MitTerPaChER, L. \& PilleR, M. (1783): Iter per Poseganam Sclavoniae provinciam mensibus Junio, et Julio Anno 1782. Buda, Typis Regiae Universitatis, $147 \mathrm{pp}$.

NeEDHAM, J. T. (1750): Nouvelles observations microscopiques, avec des découvertes intéressantes sur la composition et la décomposition des corps organisés. Ganeau, Párizs, 542 pp.

Pethe, F. (1805): Pallérozott mezei gazdaság. Sopron, Szüz, 3 köt.

Pray, Gy. (1749): De institutione ac venatu falconum libri duo. Nagyszombat, Typ. Acad. SJ, 60 pp.

RÉAUMUR, R.-A. F. de (1737-1741): Memoires pour servir a l'histoire de insectes. Amszterdam, Mortier, 10 köt. https://doi.org/10.5962/bhl.title.34136

RÉAUMUR, R.-A. F. de (1749): Art de faire éclorre et d'elever en toute saison des oiseaux domestiques de toutes especes, soit par le moyen de la chaleur du fumier, soit par le moyen de celle du feu ordinaire. L'Imprimerie Royale, Párizs, 2 köt.

RIEM, J. (1775): Fundamentalgesetze zu einer perennierenden Kolonie-Bienenpflege in zusammengesetzten Halbwohnungen. Mannheim \& Berlin, Schwan \& Decker, 448 pp.

Rohlwes, J. N. (1814): Baromorvos könyv (ford. Pethe, F.). Kolozsvár, Nemzeti Gazda, 210 p.

SAllai, Á. \& SzABÓ, Á. (2018): Az Akadémiai Könyvtár Teleki-állományának magyar vonatkozású botanikai és zoológiai könyvei. Magyar Könyvszemle 134(4): 381-410.

SÁrKöZy, E, (2012): Beszélgetés a „zöld gróffal”, Teleki Gézával, Élet és Tudomány 67(3): 76-78.

Scopoli, G. A. (1769): Einleitung zur Kenntniss und Gebrauch der Fossilien. Riga \& Mietau, Hartknoch, 213 pp.

SEVERINI, J. (1779): Tentamen zoologiae Hungaricae. Pozsony, Patzko, 113 pp.

Somkuti, G. (1966): Korszerü természettudományos irodalom Széchényi Ferenc és Teleki László könyvtárában. In: Bélley, P., HaRAszThy, Gy. \& KereszTury, D. (eds): Az Országos Széchényi Könyvtár évkönyve 1963-1964: 187-209.

SomkUTI, G. (1967): Korszerű természettudományos irodalom Széchényi Ferenc és Teleki László könyvtárában (II.). In: BÉlley, P., HARASZThy, Gy. \& KereszTury, D. (eds): Az Országos Széchényi Könyvtár évkönyve 1965-1966: 408-428.

SzEnT-Györgyi, J. (1803): A legnevezetesebb természeti dolgok esméreti (I). Debrecen, Szigethy, 379 fol.

SzIGETI, Gy. (1763): Méhész könyv. Nagyenyed, s. n., 58 pp.

SzILÁDy, Z. (1922): A magyar állattani irodalom repertoriuma I, A legrégebbi időktöl 1870-ig. Kir. M. Természettudományi Társulat, Budapest, 24 pp.

TAм, F. J. (1764): Vierfaches Kleeblatt : Hilfsmittel für Horn-, Schaf-, Pferd- und Federvieh. Bécs \& Prága, Trattner, $605 \mathrm{pp}$.

TessediK, S. (1786): A paraszt ember Magyar Országban, Engel, Pécs, 510 pp.

Tolnay, S. (1816): A lovak külső szép, vagy rút termetek s hibái meg-esméréséröl, és azoknak belső, s külső betegségeik orvoslásáról. Buda, Magyar Királyi Univerzitás, 228 pp.

TuRóczy L. (1729): Ungaria suis cum regibus compendio data. Nagyszombat, Typis Academicis, $250 \mathrm{pp}$. 
SALlai Á. \& SZABÓ Á.

Werner, A. G. (1785): Von den äusserlichen Kennzeichen der Fossilien. Bécs, Trattner, 238, pp.

Szerző nélkül (1752): Der nach medicinischen Lehrsätzen sicher und gewiss curirende Pferdearzt. Lipcse, Gessner, 294 pp.

Szerző nélkül (1767): Hinlängliche Anleitung zur Seidenzucht und zuverlässige Anweisung. Ulm, Bartholomäi, 76 pp.

Szerző nélkül (1800): Gründlicher Unterricht in der Taubenzucht. Berlin, Maurer, 48 pp. 


\section{Függelék}

\section{A Magyar Tudományos Akadémia Könyvtár és Információs Központ alapító állományában található állattani témájú könyvek listája}

Az egyes tételeknél szereplő információk, sorrendben: szerző, cím, megjelenés helye, kiadó, kiadás éve, oldalszám/kötetszám (szögletes zárójelben a számozatlan oldalak száma), rét-nagyság, megjegyzés.

A megjegyzések kódjai:

B: Teleki-bélyegzővel ellátott kötet(ek)

BN: Teleki-bélyegzővel nem rendelkező kötet(ek)

H: a könyvtár mai állományából hiányzó kötet(ek)

*: A könyv Magyarországon eddigi ismereteink szerint csak a Pannonhalmi Főapátság Könyvtárában és a Magyar Tudományos Akadémia Könyvtárában található meg.

1.) Aldrovandi, Ulisse: De reliquis animalibus exanguibus. Bologna, Ferronii, 1642. [3] fol., 593 p., [14] fol. $2^{\circ}-\mathrm{B}$

2.) AlletZ, Pons-Augustin: Histoire des singes, et autres animaux curieux. Frankfurt, Aux Depens de la Compagnie, 1769.173 p. $12^{\circ}-\mathrm{B}$

3.) APÁCZAi Csere, János: Magyar encyclopaedia. Utrecht, Waesberge, 1653. [40], 487 p. $8^{\circ}-\mathrm{BN}$

4.) BAZIN, Gilles-Augustin: Abrégé de l'histoire des insectes. Párizs, Panckoucke, 1764. 2 köt. $8^{\circ}-\mathrm{B}$

5.) BechsteIn, Johann Matthias: Gemeinnützige Naturgeschichte Deutschlands nach allen drey Reichen : ein Handbuch zur deutlichen und vollständigeren Selbstbelehrung besonders für Forstmänner, Jugendlehrer und Oekonomen. Lipcse, Crusius, 1789-95. 4 köt. $8^{\circ}$ - BN

6.) Bechstein, Johann Matthias: Naturgeschichte der Stubenvögel. Gotha, Ettinger, 1795. 2 köt. $8^{\circ}-\mathrm{H}$

7.) BeChSteIN, Johann Matthias: Naturgeschichte oder Anleitung zur Kenntni $\beta$ und Wartung der Säugethiere, Amphibien, Fische, Insecten und Würmer. Gotha, Ettinger, 1797. [18] 312, [7] p. $8^{\circ}$ $-\mathrm{B}$

8.) BÉL, Mátyás: Hungariae antiquae et novae prodromus. Nürnberg, Monath, 1723. [18], 204 p., 3 t. $2^{\circ}-\mathrm{B}$

9.) BenKő, József: Transsilvania, sive magnus Transsilvaniae Principatus, olim Dacia Mediterranea dictus. orbi nondum satis cognitus. nunc multifariam, at strictim illustratus. Bécs, Kurzböck, 1778. 2 köt. $8^{\circ}-\mathrm{BN}$

10.) BERGEN, Johann Christian: Anleitung zur Viehzucht oder vielmehr zum Futtergewächsbau und zur Stallfütterung des Rindviehes. Berlin, Realschulbuchhandlung, 1810. [6], LVIII, 482, [2] p., 3 t. - B

11.) BERNHARDI, Johann Jakob: Annalen des Nationalmuseums der Naturgeschichte zu Paris. Hamburg \& Mainz, s. n., 1803-04. 2 köt. $4^{\circ}-\mathrm{H}$ 
12.) BERTRAND, Élie: Dictionnaire universel des Fossiles propres et des Fossiles accidentels, contenant une description des terres, des sables, des sels, des soufres, des bitumes, des pierres simples \& composées, etc. Hága, Grosse - Pinel, 1763. XXXII, 606 p. $8^{\circ}-\mathrm{B}$

13.) BERTUCH, Friedrich Justin: Novus orbis pictus juventuti instituendae et oblectandae. Bécs, Pichler, 1807-08. 4 köt. $4^{\circ}-\mathrm{BN}$

14.) BLOCH, Marcus Eliezer: Oeconomische Naturgeschichte der Fische Deutschlands. Berlin, Hesse - Buchhandlung der Realschule, 1782-84. 3 köt. $4^{\circ}-\mathrm{B}$

15.) BLOCH, Marcus Eliezer: Oeconomische Naturgeschichte der ausländischen Fische, Berlin, Buchhandlung der Realschule - Morino \& Comp., 1785-91. 5 köt. $4^{\circ}-\mathrm{B}$

16.) Blumenbach, Johann Friedrich: Handbuch der Naturgeschichte. Dieterich, Göttingen, 1779. 559 p. $8^{\circ}-\mathrm{BN}$

17.) Blumenbach, Johann Friedrich: Handbuch der Naturgeschichte. Göttingen, Dieterich, 1797. IXVIII, 714, [32] p., 1 t. $8^{\circ}-\mathrm{H}$

18.) Blumenbach, Johann Friedrich: Handbuch der Naturgeschichte. Göttingen, Dieterich, 1799. [14], 708 p. $8^{\circ}-\mathrm{B}$

19.) BluMENBACH, Johann Friedrich: Abbildungen naturhistorischer Gegenstände. Göttingen, 1810. [10], [210] p. $8^{\circ}-\mathrm{H}$

20.) BoerhaAve, Herman, Flloyd, Thomas, Hill, John \& Swammerdam, Jan: The Book of Nature; or, the History of Insects. London, Seyffert, 1758. XX, [8], 236, 153, LXIII, 12 p. $2^{\circ}-\mathrm{B}$

21.) BoHADSCH, Joannes Baptist: De quibusdam animalibus marinis. Drezda, Walther, 1761. [18], 169 p. 12 t. $4^{\circ}-\mathrm{B}$

22.) Bolten, Joachim Friedrich: Ad illustrem systematis naturae authorem Carolum a Linné equitem auratum epistola de novo quodam Zoophytorum genere. Hamburg, Herold, 1771. 12 p., 1 t. $4^{\circ}-\mathrm{B}$

23.) Valmont-Bomare, Jacques Christoph: Dictionnaire raisonné universel d'Histoire naturelle; contenant l'histoire des animaux, des végétaux et des minéraux. Párizs, Lacombe, 1767-68. 6 köt. $8^{\circ}-\mathrm{B}$

24.) Bonnet, Charles: Contemplation de la nature, Yverdon, s. n., 1767. 2 köt. $8^{\circ}-\mathrm{H}$

25.) Bonnet, Charles: Considérations sur les corps organisés. Amszterdam, Rey, 1768. [50], 234 p. ; [16], 280 p. $8^{\circ}-\mathrm{B}$

26.) BonNeT, Charles: Betrachtungen über die Natur. Lipcse, Junius, 1772. CVI, 562 p., [7] p. $8^{\circ}-$ BN

27.) Bonnet, Charles: Oeuvres d'histoire naturelle et de philosophie de Charles Bonnet. Neuchatel, Fauche, 1779-81. 7 köt. $4^{\circ}-\mathrm{B}$

28.) ${ }^{1}$ BoRKHAUSEN, Moritz Balthazar: Teutsche Ornithologie oder Naturgeschichte aller Vögel Teutschlands in naturgetreuen Abbildungen und Beschreibungen. Darmstatt, Wittich, 1800. 123 p. $2^{\circ}-\mathrm{BN}$

29.) BoRN, Ignaz von: Briefe über mineralogische Gegenstände, auf seiner Reise durch das Temeswarer Bannat, Siebenbürgen, Ober- und Nieder-Hungarn an den Herausgeber derselben, Johann Jacob Ferber geschrieben. Frankfurt - Lipcse, s. n., 1774. [12], 228 p. $8^{\circ}$ - B

30.) Born, Ignaz von: Testacea Musei Caesarei Vindobonensis, quae jussu Mariae Theresiae Augustae disposuit et descripsit Ignatius a Born. Bécs, Kraus, 1780. XXXVI, 442, [17] p. $2^{\circ}-$ B

\footnotetext{
${ }^{1}$ A kéziratos listán cím helyett, témamegjelölésként az "Ornithologia Germanica" kifejezés szerepel, ami valószínüleg erre a kiadványra vonatkozik.
} 
31.) Born, Ignaz von: Catalogue méthodique et raisonné de la collection des fossiles de Mlle Éléonore de Raab. Bécs, Degen, 1790. 4 köt. $8^{\circ}-\mathrm{B}$

32.) BorOwsKI, Georg Heinrich: Gemeinnützige Naturgeschichte des Thierreichs. Berlin Stralsund, Lange, 1780-84. 5 köt. $8^{\circ}-\mathrm{H}$

33.) BouRguet, Louis: Lettres philosophiques sur la formation des sels et des crystaux et sur la génération et le mechanisme organique des plantes et des animaux. Amszterdam, l'Honore, 1729. [44], 220 p. $8^{\circ}-\mathrm{BN}$

34.) BuchOZ, Pierre Joseph: Oekonomisch-physikalische Abhandlung vom Federvieh. Bécs, Trattner, 1785. [32], 256 p. $8^{\circ}-\mathrm{B}$

35.) BufFOn, George Louis Leclerc: Histoire naturelle des oiseaux. Párizs, Impr. Royale, 1770-80. 14 köt. $8^{\circ}-\mathrm{B}$

36.) BufFON, George Louis Leclerc: Allgemeine Naturgeschichte. Berlin, Pauli, 1771-74. 7 köt. $8^{\circ}-$ $\mathrm{B}$

37.) BufFON, George Louis Leclerc: Naturgeschichte der Vögel. Berlin, Pauli, 1772-77. 6 köt. $8^{\circ}-$ $\mathrm{B}$

38.) BuFFON, George Louis Leclerc: Oeuvres complètes : histoire naturelle, générale et particulière. Párizs, Impr. Royale, 1774-85. 43 köt. $8^{\circ}-\mathrm{B}$

39.) BufFON, George Louis Leclerc: Naturgeschichte der vierfüssigen Thiere. Troppau, s. n., 178586.2 köt. $8^{\circ}-\mathrm{BN}$

40.) CAIUS, John: De canibus Britannicis, lib. 1. : De rariorum animalium et stirpium historia, lib. 1. De libris propriis, lib. 1. De pronunciatione Graecae et Latinae linguae. London, Davis, 1729. $\mathrm{XV}, 249,[7]$ p. $8^{\circ}-\mathrm{BN}$

41.) CARENO, Luigi: Ueber die Kuhpocken: eine Volksschrift. Bécs, Camesina, 1801. [8], 30, [2] p. $8^{\circ}-\mathrm{BN}$

42.) CARENo, Luigi: A tehén-himlöről (ford. BÉRCZy János). Pest, 1802. 123 p. $8^{\circ}-\mathrm{H}$

43.) CAVENDISH, William: Die neueste Lehr-Art und besondere Erfindung die Pferde zu dressiren, oder abzurichten und zu arbeiten, und zwar nach der Natur, welche durch subtile Kunst-Griffe zur Vollkommenheit gebracht wird. Nürnberg, Lochner, 1729. [30], 470 p. $8^{\circ}-\mathrm{H}$

44.) Christ, Johann Ludwig: Anweisung zur nützlichsten und angenehmsten Bienenzucht. Frankfurt - Lipcse, Fleischer, 1783. XLVIII, 354, [14] p. $8^{\circ}$ - B

45.) ConRaD, József: Philosophia historiae naturalis. Bécs, Schulz, 1779. 84 p. $8^{\circ}$ (2 példányban) B

46.) Coulet, Etienne: Tractatus historicus de ascaridibus, et lumbrico lato. Leiden, Potuillet, 1729. [32], 228, [1] p. $8^{\circ}-\mathrm{B}$

47.) CRAMER, Pieter: De uitlandische kapellen voorkomende in de drie waereld-deelen Asia, Africa en America / Papillons exotiques des trois parties du monde l'Asie, l'Afrique et l'Amerique. Amszterdam - Utrecht, Baalde - Wild, 1779-84. 3 köt. $4^{\circ}$ - B

48.) Cuvier, Georges: Le régne animal. Párizs, Deterville, 1817. 4 köt. $8^{\circ}-\mathrm{B}$

49.) CseKonics, József: Praktische Grundsätze die Pferdezucht betreffend. Pest, s. n., 1817. XVIII, 232 p. $8^{\circ}-\mathrm{BN}$

50.) CsiBA, Mihály István: Dissertatio historico-physica de montibus Hungariae. Nagyszombat, Typis Academicis, 1714. [4], 140, [5] p. $8^{\circ}-\mathrm{H}$

51.) DECKER, Johann Matthias: Naturgeschichte aus den besten Schriftstellern mit Merianischen und neuen Kupfern. Heilbronn, Eckebrechtische, 1774-78. 4 köt. $2^{\circ}-\mathrm{B}$ 
52.) Denis, Michael \& SCHIFFERMÜLLER, Ignaz: Ankündung eines systematischen Werkes von den Schmetterlingen der Wienergegend. Bécs, Bernardi, 1775. [2], 322, [1] p. $4^{\circ}-\mathrm{H}$

53.) DEZALLIER, Antoine-Joseph: L'histoire naturelle éclaircie dans deux de ses parties principales, la lithologie et la conchyliologie, dont l'une traite des pierres et l'autre des coquillages. Párizs, Chez de Bure l'aìné, 1742. [8], 394. $4^{\circ}-\mathrm{H}$

54.) DonOvan, Edward: Natur-Geschichte der chinesischen Insekten. Lipcse, Industrie Comptoir, s. a. 40 p. $4^{\circ}-\mathrm{B}$

55.) DRURY, Dru: Abbildungen und Beschreibungen exotischer Insekten, mit sein illuminirten Kupfertafeln. Nürnberg, Winterschmidt, s. a. [4], 203, [5] p., 22 t. $4^{\circ}-$ B

56.) Dubois de Jancigny, Jean-Baptiste: Tableau annuel des progrés de la physique, de l'histoire naturelle et des arts. Varsó, Poser, 1772. XVI, 530, [2] p. $8^{\circ}-\mathrm{B}$

57.) EBERT, Johann Jacob: Naturlehre für die Jugend. Lipcse, Weidmann, 1776-77. 3 köt. $8^{\circ}-\mathrm{B}$

58.) ÉDER, Xavér Ferenc: Descriptio provinciae Moxitarum in regno Peruano quam e scriptis posthumis Franz Xav. Eder e Soc. Jesu annis XV. sacri apud eosdem curionis digessit, expolivit, et adnotatiunculis illustravit abb. et consil. reg. Mako. Buda, Typis Universitatis, 1791. XVIII, 383 p., 10 t. $8^{\circ}-\mathrm{BN}$

59.) EICHHORN, Johann Conrad: Beyträge zur Naturgeschichte der kleinsten Wasserthiere die mit blossem Auge nicht können gesehen werden und die sich in den Gewässern in und um Danzig befinden. Berlin - Stettin, Nicolai, 1781. 94 p., 8 t. $8^{\circ}-\mathrm{H}$

60.) ELLIS, Jean: Essai sur l'histoire naturelle des corallines. Hága, Hondt, 1756. XVI, 125, [3] p., 39 t. $4^{\circ}-\mathrm{B}$

61.) ESPER, Eugen Johann Christoph: Die Schmetterlinge in Abbildungen nach der Natur mit Beschreibungen. Erlangen, Walthers, 1777-86. 5 köt. $4^{\circ}-\mathrm{B}$

62.) EYRICH, Johann Leonhard: Gesammelte und nach Vernunft und Erfahrung geprüfte Nachrichten von der Winterung der Bienen. Nürnberg, Zeh, 1774. 110 p. $8^{\circ}-\mathrm{B}$

63.) Fichtel, Johann Ehrenreich von: Beytrag zur Mineralgeschichte von Siebenbürgen. Nürnberg, Verlag der Raspischen Buchhandlung, 1780. 158 p., 7 t. $4^{\circ}-\mathrm{H}$

64.) FichTEL, Johann Ehrenreich von: Mineralogische Bemerkungen von den Karpathen. Bécs, Kurzbeck, 1791. 2 köt. $8^{\circ}-\mathrm{B}$

65.) Fichtel, Leopold von: Testacea microscopica aliaque minuta ex generibus Argonauta et Nautilus = Microscopische und andere kleine Schalthiere aus den Geschlechtern Argonaute und Schiffer. Bécs, Camesina, 1803. XII, [4], 123, [1] p., 24 t. $4^{\circ}-$ B

66.) FISCHER, Gottlob Eusebius: Vollständiges Handbuch einer technologischen und ökonomischen Naturgeschichte für deutsche Bürger, Landwirthe und ihre Kinder : des ersten Theils, oder der Thierbeschreibung. Lipcse, Gerhard, 1797. XIV, [2], 264 p., 14 t. $8^{\circ}-\mathrm{BN}$

67.) FoRSSKÅL, Peter: Descriptiones animalium. Koppenhága, Möller, Heineck \& Faber, 1775. 164 p. $4^{\circ}-\mathrm{B}$

68.) FourCroy, Antoine François de: Élémens d'histoire naturelle et de chimie. Párizs, Cuchet, 1791.5 köt. $8^{\circ}-\mathrm{B}$

69.) FrAnZ, Wolfgang: Historia animalium, Drezda, Hübner, 1687. [46], 326 p. $12^{\circ}-\mathrm{H}$

70.) FRANZ, Wolfgang: Historia animalium. Frankfurt - Lipcse, Lesch, 1712. 2 köt. $4^{\circ}-\mathrm{B}$

71.) FrIDVALSZKY, János: Mineralogia magni principatus Transsylvaniae. Kolozsvár, Typis Academicis Societatis Iesu, 1767. [8], 206, [6] p., 5 t. $4^{\circ}-\mathrm{BN}$

72.) FunKe, Carl Philipp: Abbildung und Beschreibung der merkwürdigsten Gegenstände aus dem Thier-, Pflanzen- und Mineralreich, Bécs, Haas, 1812. [4] p., 24 t. - H 
73.) GÁTI, István: A természet históriája. Máramarossziget, s. n., 1792. 32 p. $8^{\circ}-\mathrm{BN}$

74.) Germershausen, Christian Friedrich: Das Ganze der Schafzucht aus Beurtheilung u. Berichtigung älterer $u$. neuerer Theorien nach Gründen und Erfahrung. Lipcse, Junius[?], 178990.2 köt. $8^{\circ}-\mathrm{BN}$

75.) GlatZ, Jakob: Naturhistorisches Bilder- und Lese-Buch. Reutlingen, Mäck, 1803. 360 p. $8^{\circ}-\mathrm{B}$

76.) GLEICHEN, Wilhelm Friedrich von: Abhandlung über die Saamen- und Infusionstierchen. Nürnberg, Winterschmidt, 1778. XII, 171, [1] p., 32 t. $4^{\circ}-\mathrm{B}$

77.) GotThaRd, Johann Christian: Das Ganze der Rindviehzucht. Erfurt, s. n., 1804. VI, 368 p. $8^{\circ}-$ $\mathrm{BN}$

78.) Gronovius, Laurentius Theodorus: Zoophylacii Gronoviani fasciculus primus. Leiden, sumpt. auct., 1763. [4], 136, II. p. 13 t. $2^{\circ}-$ B

79.) Grossinger, János: Universa Historia Physica regni Hungariae secundum tria regna naturae digesta. Pozsony, Weber, 1793-97. 5 köt. $8^{\circ}-\mathrm{BN}$

80.) GuAlteri, Nicolaus: Index testarum conchyliorum quae adservantur in musaeo Nicolai Gualteri. Firenze, Albizzini, 1742. XXIII p., 110 t, [1] p. $2^{\circ}-\mathrm{B}$

81.) HANDERLA, György: Új méhész, vagy-is a méheknek magyar hazánkhoz alkalmaztatott gondviselése. Pozsony, Weber, 1810. VI., [2], 174 p. $8^{\circ}-\mathrm{B}$

82.) HARVEY, William: Exercitationes de generatione animalium. Hága, Leers, 1680. [32], 582, [8] p. $8^{\circ}-\mathrm{B}$

83.) HASTFER, Friedrich Wilhelm: Ausführlicher Unterricht von der Zucht und Wartung der besten Art von Schafen. Lipcse, Heinsius, 1785. XXIV, 248 p. $8^{\circ}-\mathrm{BN}$

84.) Helmuth, Johann Heinrich: Gemeinnützige Naturgeschichte des In- und Auslandes. Bécs, Doll, 1808.8 köt. $8^{\circ}-\mathrm{B}$

85.) HeRBST, Johann Friedrich Wilhelm: Versuch einer Naturgeschichte der Krabben und Krebse. Berlin - Stralsund, Lange, 1790-99. 3 köt. $4^{\circ}-\mathrm{B}$

86.) HIRSCH, J. Сн. (1764): Der redliche Schäffer, oder umständliche Beschreibung einer Schäfferey. Anspach, Posch, 1764. 118, [6] p., s1 t. $8^{\circ}-\mathrm{B}$

87.) Hiver, Joseph: Englische Zucht und Behandlung der Pferde. Bécs, Wappler, 1783. [2], 109 p. $8^{\circ}-\mathrm{B}$

88.) Hoffmann, Gottfried Daniel: Observationes circa Bombyces, Sericum et Moros ex antiquitatum, historiarum, juriumque penu depromptae. Tübingen, Erhard, 1757.48 p. $8^{\circ}-\mathrm{B}$

89.) HoffmannsegG, Johann Centurius von: Reise des Grafen von Hofmannsegg in einige Gegenden von Ungarn bis an die türkische Gränze : ein Auszug aus einer Sammlung von original Briefen. Görlitz, Anton, 1800. VIII, 246, [1] p. $8^{\circ}-\mathrm{BN}$

90.) HöcK, Johann Daniel Albrecht: Oekonomische Abhandlung von der Schweinszucht. Frankfurt, Jäger, 1792.38 p. $8^{\circ}-\mathrm{H}$

91.) HÖGElmüLleR, Georg von \& Wolstein, Johann Gottlieb: Tractatus de vulnerationibus equorum, per arma instictis, pro veterinariis belli tempore. Bécs, Camesina, 1803. IV., 194. p. $8^{\circ}$ $-\mathrm{H}$

92.) Holandre, François: Planches pour l'abrégé d'histoire naturelle. Zweibrücken, Sanson \& Comp., 1790. 2 köt. $8^{\circ}-\mathrm{B}$

93.) Holandre, François: Abrégé d'histoire naturelle des quadrupédes vivipares et des oiseaux. Zweibrücken, Sanson \& Comp., 1790. 6 köt. $8^{\circ}-\mathrm{H}$

94.) JACQUIN, Nicolaus Joseph: Miscellanea Austriaca ad Botanicam, Chemiam, et historiam naturalem spectantia. Bécs, Kraus, 1778-81. 2 köt. $4^{\circ}-\mathrm{B}$ 
95.) JANSCHA, Anton: Hinterlassene vollständige Lehre von der Bienenzucht. Bécs, Kurzbeck, 1790. [8], 204, [10] p., 4 t. $8^{\circ}-\mathrm{B}$

96.) JaUfFret, Louis-François: Voyage au jardin des Plantes. Párizs, Houel, 1797. VIII, 244 p. $8^{\circ}-$ $\mathrm{H}$

97.) Jonston, Jan: Historiae naturalis de avibus libri VI. Frankfurt - Lipcse, Merian, 1650. 227 p. 62 t. $2^{\circ}-\mathrm{H}$

98.) JONSTON, Jan: Theatrum universale omnium animalium quadrupedum. Heilbronn, Eckebrecht, 1755. [8] fol., 236 p., 80 t. $2^{\circ}-\mathrm{B}$

99.) *Jonston, Jan: Ioannis Ionstoni theatrum universale de avibus. Heilbronn, Lannoy, 1756. [8], $238,[10]$ p., 62 t. $2^{\circ}-\mathrm{B}$

100.) Jonston, Jan: Historiae naturalis de serpentibus libri duo. Heilbronn, Eckebrecht, 1757. 55, [3] p. $2^{\circ}-\mathrm{B}$

101.) Jonston, Jan: Historiae naturalis de piscibus et cetis libri V. Frankfurt, Merian, [1650]. 228, [10] p. $2^{\circ}-\mathrm{B}$

102.) Jonston, Jan: Historiae naturalis de quadrupedibus libri. Frankfurt, Merian, 1652[?]. [2], 231, [5] p., 80 t. $2^{\circ}-\mathrm{B}$

103.) KeRESZTÚRI, József, ReIFF, Jakab Ignác \& Tichy, István: Tentamen publicum ex regno animali quod in regia universitate Budensi anno 1779 subibunt. Buda, Typis Regiae Universitatis, 1779. 46 p. $8^{\circ}-\mathrm{B}$

104.) KleEmann, Christian Friedrich Carl: Beiträge zur Natur- und Insektengeschichte. Nürnberg, Bauer und Raspe, 1792. 2 köt. $4^{\circ}-\mathrm{H}$

105.) KLEIN, Mihály: Sammlung der merkwürdigsten Naturseltenheiten des Königreiches Ungarn. Pozsony \& Lipcse, Löwe, 1778. [15], 126, [17] p. $8^{\circ}-\mathrm{BN}$

106.) KLEIN, Jacob Theodor: Historiae avium prodromus. Schmidt, Lübeck, 1750. [16], 238 p. $4^{\circ}-$ B

107.) KleIN, Jacob Theodor: Descriptiones tubulorum marinorum. Danzig \& Lipcse, Gleditsch, 1773. 44 p., 10 t. $4^{\circ}-\mathrm{B}$

108.) KLOBB, Heinrich Eduard: Abhandlung von den Hauptkrankheiten und Verhalten der Schaafe. Regensburg, Montag, 1790.77 p. $8^{\circ}-\mathrm{B}$

109.) KocZian, Anton: Prüfung der Ursachen von der Hornviehseuche. Bécs, Kurzböck, 1769. [2], $174,[2]$ p. $8^{\circ}-\mathrm{BN}$

110.) Kraus, Johann Ernst: Der edle Gestütt-Garten oder aufrichtige Anleitung zur Gestütt- und Pferd-Zieglung, auch Maulthier-Zucht; Die Instruction eines Gestütt-Meisters, die FutterOrdnung, und der Nutzen von der Fohlen und Maulthier-Zucht. Rüdiger, Nürnberg, 1724. 233 p. $8^{\circ}-\mathrm{BN}$

111.) KRÜGER, Johann Gottlob: Naturlehre (II-III.). Halle, Hemmerde, 1748-50. 2 köt. $8^{\circ}$ - B

112.) KRÜGER, Johann Gottlob: Naturlehre, nebst Kupfern und vollständigen Register. Halle, Hemmerde, 1771. XXII, [1], 920 p., 14 t. $8^{\circ}-\mathrm{B}$

113.) KRÜGER, Johann Gottlob: Elementa philosophiae naturalis. Kolozsvár, Colleg. Ref., 1774. [16], $386,[28]$ p. : 1 t. $8^{\circ}-\mathrm{B}$

114.) KRÜGER, Johann Gottlob: Philosophia naturalis experimentis confirmata. Halle, Hammerde, 1753. [16], 992, [62] p., 14 t. $8^{\circ}-$ B

115.) LA CÉPÈDE, Bernard-Germin Étienne: Histoire naturelle des quadrupèdes ovipares et des serpens. Párizs, Hotel de Thou, 1788-90. 4 köt. $8^{\circ}-\mathrm{BN}$

116.) LeVaillant, François: Histoire naturelle des oiseaux d'Afrique. Párizs, Fuchs \& Delachaussée, 1799-1806. 5 köt. $4^{\circ}-\mathrm{B}$ 
117.) LinNÉ, Carl von: Vollständiges Natursystem. Nürnberg, Raspe, 1773-76. 9 köt. $8^{\circ}$ - BN

118.) LinNÉ, Carl von: Entomologia, Faunae Suecicae descriptionibus aucta. Lyon, Delamollier, 1789. 4 köt. $8^{\circ}-\mathrm{BN}$

119.) LiPPAY, János: Posoni kert. Győr, Streibig, 1753. [2], 686, [10] p. $4^{\circ}-\mathrm{H}$

120.) Lossius, Friedrich David: Die beste und natürlichste Behandlung der Schaafe dieselben vor allerlei bösartigen Zufällen zu verwahren und die Schäfereien in Aufnahme zu bringen. Lipcse, Böhme, 1791. 16, [10], 260 p. $8^{\circ}-\mathrm{B}$

121.) LÖHNEISEN, Georg Engelhard von: Neu-eröffnete Hof-Kriegs- und Reit-Schul, das ist gründlicher Bericht della cavalleria, oder von allen, was zur Reuterey gehörig und einem Cavalier davon zu wissen gebühret, nach den ersten titul dieses überaus rar-wordenen Buches, welches aber-anjezto in einem gantz andern Stand gesetzet, verneuert, und mit ausführlichen schönen Noten, auch gantzen Capiteln vermehret und verbessert worden. Nürnberg, Lochner, 1729. [30], 66, 96, 114 p., 4 t. $2^{\circ}-$ B

122.) MaRTINI, Friedrich Heinrich Wilhelm: Allgemeine Geschichte der Natur in alphabetischer Ordnung mit vielen Kupfern nach Bomarischer Einrichtung. Berlin, Pauli, 1774-78. 4 köt. $8^{\circ}$ - B

123.) Mattioli, Pietro Andrea: Commentarii secundo aucti, in libros sex Pedacii Dioscoridis Anazarbei de medica materia. Adiectis quam plurimis plantarum, \& animalium imaginibus, quae in priore ed. non habentur. Velence, Valgrisius, 1558. [100], 776 p. ; 50 p. $2^{\circ}-\mathrm{B}$

124.) Mattioli, Pietro Andrea: Commentarii secundo aucti, in libros sex Pedacii Dioscoridis Anazarbei de medica materia. Adiectis quam plurimis plantarum, \& animalium imaginibus, quae in priore ed. non habentur. Velence, Valgrisius, 1559. [82], 776 p. $2^{\circ}-\mathrm{B}$

125.) MÁTyUs, István: $O$ és új diaetetica az az, Az életnek és egésségnek fenn-tartására és gyámolgatására Istentől adattatott nevezetesebb természeti eszközöknek a szerint való elészámlázása a mint azokra reá kaptak, és eleitöl fogva min ez ideig magok károkra vagy hasznokra vélek éltek az emberek. Pozsony, Landerer, 1787-92. 5 köt. $8^{\circ}-\mathrm{B}$

126.) MeISNER, C. H. [= TouChy, Ferdinand Christian]: Handbuch zum nützlichen Gebrauche für Pferdeeigenthümer, Bereiter, Pferdeverleiher und für Stadt- und Dorfschmiede; oder gründlicher Unterricht, wie gute Pferde zu erziehen, und wie die gewöhnlichen Krankheiten dieser Thiere geschwinde und sicher zu heilen; deßgleichen, wie man sich beym Einkaufe der Pferde zu verhalten habe, um nicht von den Roßhändlern betrogen zu werden. Lipcse, s. n., 1806. 436 p. $8^{\circ}$ $-\mathrm{H}$

127.) Mellin, August Wilhelm von: Versuch einer Anweisung zur Anlegung, Verbesserung und Nutzung der Wildbahnen sowohl im Freyen als in Thiergärten. Pauli, Berlin - Stettin, 1779. XXI, 356 p. $4^{\circ}-\mathrm{B}$

128.) Michelet, Jules: Aus den Lüften - Das Leben der Vögel. Wolff, Berlin, 1859. [2], 281 p. $8^{\circ}-$ B

129.) MiskolCZi, Gáspár: Egy Jeles Vad-Kert. Kolozsvár, s. n., 1769. [16], 731, [5] p. $8^{\circ}-\mathrm{H}$

130.) MitTERPACHER, Lajos: Elementa rei rusticae in usum academiarum regni Hungariae. Buda, Typis Regiae Universitatis, 1777-94. 3 köt. $8^{\circ}-\mathrm{B}$

131.) MITTERPACHER, Lajos: Elementa rei rusticae in usum academiarum regni Hungariae (I-II). Buda, Typis Regiae Universitatis, 1777-79. 2 köt. $8^{\circ}-\mathrm{BN}$

132.) MITTERPACHER, Lajos: Elementa rei rusticae in usum academiarum regni Hungariae (I). Buda, Typis Regiae Universitatis, 1777. 196 p. $8^{\circ}-\mathrm{B}$

133.) MITTERPACHER Lajos \& PILLER Mátyás: Iter per Poseganam Sclavoniae provinciam mensibus Junio, et Julio Anno 1782. Buda, Typis Regiae Universitatis, 1783.147 p., 10 t. $4^{\circ}$ - BN 
134.) Monceau, Henri Louis Duhamel du - Schreber, D. G.: Allgemeine Abhandlung von den Fischereyen Atlas. Lipcse - Königsberg, Kanter, 1773. [10], 204 p., 21 t.; 438 p., 50 t.; 328 p., 15 t. $4^{\circ}-\mathrm{B}$

135.) NeEDHAM, John Turberville: Nouvelles observations microscopiques, avec des découvertes intéressantes sur la composition et la décomposition des corps organisés. Ganeau, Párizs, 1750. 18,524 p., 8 t. $8^{\circ}-\mathrm{B}$

136.) PaLlas, Peter Simon: Miscellanea zoologica, quibus novae imprimis atque obscurae animalium species describuntur et observationibus iconibusque illustrantur. Hága, Cleef, 1766. [10], 224 p., 14 t. $4^{\circ}-\mathrm{BN}$

137.) PETÉNYI, Salamon János: Pár szó az emlősökről általában és a magyarhoniakról különösen. Pest, Trattner-Károlyi, 1844. 15 fol. $4^{\circ}-\mathrm{B}$

138.) Pethe, Ferenc: Pallérozott mezei gazdaság. Sopron, Szüz, 1805. 3 köt. $8^{\circ}-\mathrm{B}$

139.) Pethe, Ferenc: Pallérozott mezei gazdaság (I). Sopron, Szüz, 1805. XXXX, 776 p. $8^{\circ}-\mathrm{B}$

140.) PETHE, Ferenc: Természet-história és mesterségtudomány a tanitók és tanulók szükségekre s az ebben gyönyörködők hasznokra. Bécs, Nemzeti Gazda Hivatal, 1815. 523, [1] p., 49 t. $8^{\circ} 2$ péld. $\mathrm{BN}$

141.) PETHE, Ferenc: Idöpróféta vagy időváltozást jövendölö pókok. Pest, Trattner, 1816. 60 fol., 1 t. $8^{\circ}-\mathrm{B}$

142.) PILLER, Mátyás: Elementa historiae naturalis in usum scholarum grammaticarum et gymnasiorum per regnum Hungariae et provincias eidem adnexas. Buda, Typ. Regiae Univ., 1779-81. 3 köt. $8^{\circ}-\mathrm{B}$

143.) PLUCHE, Noel-Antoine: Neuer Schauplatz der Natur oder Beyträge zur Verherrlichung Gottes und zur Ausbreitung gemeinnütziger Kenntnisse in einem freyen Auszuge des Plüschischen Werkes mit neuen Erfahrungen vermehrt und verbessert (I). Frankfurt - Lipcse, Monath, 1772. [14], 552 p. $8^{\circ}-\mathrm{H}$

144.) Pluche, Noel-Antoine: Le spectacle de la nature ou Entretiens sur les particularités de l'histoire naturelle, Neaulme, Hága, 1735-39. 4 köt. $12^{\circ}-\mathrm{B}$

145.) PRAY, György: De institutione ac venatu falconum libri duo. Nagyszombat, Typ. Acad. SJ, 1749. [6], 54 p. $8^{\circ}-\mathrm{BN}$

146.) Prizelius, Johann Gottfried: Handbuch der Pferdewissenschaft zu Vorlesungen. Lemgo, Mayer, 1775.160 p. $8^{\circ}-\mathrm{B}$

147.) RAFF, Georg Christian: Naturgeschichte für Kinder. Göttingen, Dieterich, 1785. [16], 800, [10] p., 14 t. $8^{\circ}-\mathrm{B}$

148.) RAFF, Georg Christian: Naturgeschichte für Kinder. Tübingen, Balz und Schramm, 1788. 258 p., 4 t. $8^{\circ}-\mathrm{H}$

149.) RÉAUMUR, René-Antoine Ferchault de: Memoires pour servir a l'histoire de insectes. Amszterdam, Mortier, 1737-41. 10 köt. $8^{\circ}-\mathrm{B}$

150.) RÉAUMUR, René-Antoine Ferchault de: Art de faire éclorre et d'elever en toute saison des oiseaux domestiques de toutes especes, soit par le moyen de la chaleur du fumier, soit par le moyen de celle du feu ordinaire. L'Imprimerie Royale, Párizs, 1749. 2 köt. $8^{\circ}$ - B

151.) REDI, Francesco: Experimenta circa res diversas naturales, speciatim illas quae ex Indiis adferuntur. Amszterdam, Frisius, 1675. 193, 111, 72, 52 p. $8^{\circ}-\mathrm{BN}$

152.) ReIMARUS, Hermann Samuel: Allgemeine Betrachtungen über die Triebe der Thiere, hauptsächlich über ihre Kunst-Triebe. Hamburg, Bohn, 1760. [16], 410, [23] p. $8^{\circ}-\mathrm{H}$

153.) RichteR, Adam Daniel: Lehrbuch einer Naturhistorie. Fulda, Stahel, 1775. 258 p. $8^{\circ}-$ BN 
154.) RIEM, Johann: Fundamentalgesetze zu einer perennierenden Kolonie-Bienenpflege in zusammengesetzten Halbwohnungen. Mannheim \& Berlin, Schwan \& Decker, 1775. XX, 424, [4] p. 1 t. $8^{\circ}-\mathrm{B}$

155.) RoHLwes, Johann Nicolaus: Baromorvos könyv (ford. Pethe, F.). Kolozsvár, Nemzeti Gazda, 1814. 210 p., 1 t. $8^{\circ}-\mathrm{H}$

156.) RoskoschNiK, Johann: Nachricht von den nach Bontzhida in Siebenbürgen gekommenen Zugheuschrecken, ihrem Aufenthalte daselbst und ihrer Ausrottung, nebst einigen die Naturgeschichte derselben betreffenden Bemerkungen. Pozsony, Löwe, 1782.14 p., 1 t. $8^{\circ}-\mathrm{B}$

157.) Rousselot, Jacques-Philibert: Mélanges intéressans et curieux ou abrégé d'histoire naturelle, morale, civile et politique de l'Asie, l'Afrique, l'Amérique et des Terres Polaires. Párizs, s. n., 1763. 288 p. $12^{\circ}-\mathrm{B}$

158.) RöSEL, August Johann: Historia naturalis Ranarum nostratium = Die natürliche Historie der Frösche hiesigen Landes. Nürnberg, Steinin, 1800. [10], VII, 115 [1] p., 24 t. $2^{\circ}-$ BN

159.) RöSEL, August Johann: Naturgeschichte der Froesche des Mittleren Teutschlands. Nürnberg, Stein, 1800-01. 70 p, 21 t. $2^{\circ}-\mathrm{BN}$

160.) RUMPF, Georg Eberhard: Thesaurus imaginum piscium testaceorum: quales sunt cancri, echini, echinometra, stella marince, etc. Leiden, Aa, 1711. [6], 15, [8] p., 60 t $2^{\circ}-\mathrm{B}$

161.) RuMPF, Georg Eberhard: Amboinische Raritätenkammer. Bécs, Kraus, 1766. CXXVIII, [2], 200, [4] p., 49 t. $4^{\circ}-\mathrm{B}$

162.) SAUNIER, Jean de: La parfaite connoissance des chevaux. Hága, Moetjens, 1734. [8], 264 p., 61 t. $2^{\circ}-\mathrm{B}$

163.) Sauvages, Boissier de: Della maniera di far nascere, e di nutrire $i$ bachi da seta; Della coltivazione de gelsi; Sull'origine del mele. Milánó, Galeazzi, 1765. 2 köt. $8^{\circ}-\mathrm{B}$

164.) ScHÄFFER, Jacob Christian: Die Sattelfliege. Regensburg, Weiss, 1753. [4], 20 p., 1 t. $4^{\circ}-$ B

165.) SCHÄFFER, Jacob Christian: Die Armpolypen in den süssen Wassern um Regensburg. Weiss, Regensburg, 1754.84 p. $4^{\circ}-\mathrm{B}$

166.) SCHÄFFER, Jacob Christian: Abhandlungen von Insekten. Regensburg, Montag, 1764. 2 köt. $8^{\circ}-\mathrm{B}$

167.) SCHÄFFER, Jacob Christian: Piscium Bavarico-Ratisbonensium pentas. Regensburg, Montag \& Weiss, 1761. [12], 82 p., 4 t. $4^{\circ}-\mathrm{B}$

168.) SCHINDELMAYER, Karl Robert: Merkwürdigkeiten der Welt, oder vorzügliche Erscheinungen der Natur und Kunst. Bécs, Schrämbl, 1806-08. 4 köt. $4^{\circ}-\mathrm{B}$

169.) Schmahling, Ludwig Christoph: Naturlehre für Schulen. Göttingen \& Gotha, Dietrich, 1774. [40], 93 p. $8^{\circ}-\mathrm{B}$

170.) SCHMIDT, Johann Gottlieb: Kupfertafel zu Blochs Fischen. s. 1., s. n., s. a. - H

171.) SCHRÖTER, Johann Samuel: Abhandlungen über verschiedene Gegenstände der Naturgeschichte. Halle, Gebauer, 1776-77. 2 köt. $8^{\circ}-\mathrm{B}$

172.) ScIlla Agostino: De corporibus marinis lapidescentibus quae defossa reperiuntur. Róma, Zempel, 1759. [4], 82, [6] p., 28 t. $4^{\circ}-\mathrm{BN}$

173.) SCOPOLI, Giovanni Antonio: Entomologia carniolica exhibens insecta Carnioliae indigena et distributa in ordines, genera, species, varietates, methodo linnaeana. Bécs, Trattner, 1763. [35], 420, [1] p. $8^{\circ}-\mathrm{BN}$

174.) Scopoli, Giovanni Antonio: Einleitung zur Kenntniss und Gebrauch der Fossilien. Riga \& Mietau, Hartknoch, 1769. [18], 195 p. $8^{\circ}-$ B 
175.) Scopoli, Giovanni Antonio: Deliciae florae et faunae Insubricae. Pavia, Typographia Reg. \& Imp. Monasterii S. Salvatoris, 1786. [4], IX, 86 p., 25 t. $2^{\circ}-\mathrm{H}$

176.) SeBA, Albert: Locupletissimi rerum naturalium thesauri accurata descriptio. Amszterdam, Waesberg, 1734-65. 4 köt. $2^{\circ}-\mathrm{B}$

177.) SELL, Godefried: Historia naturalis teredinis seu xylophagi marini, tubulo-conchoidis speciatim Belgici. Utrecht, Besseling, 1733. [34], 375 p. $4^{\circ}-\mathrm{BN}$

178.) SeVerini, János: Tentamen zoologiae Hungaricae. Pozsony, Patzko, 1779. [2], 111 p. $8^{\circ} 2$ péld. B

179.) SIND, Johann Baptist von: Gründlicher Unterricht von der Pferdezucht. Frankfurt \& Lipcse, Brönner, 1769. [24], 231 p., 2 t. $8^{\circ} \mathrm{BN}$

180.) SPENER, Christian Maximilian: Catalogus Zahlreicher, nützlicher, und sonderbahrer von Naturund Kunst gebildeter Seltenheiten. Berlin, Schlechtiger, 1718. 208 p. $8^{\circ}-\mathrm{B}$

181.) StÜtZ, Andreas: Neue Einrichtung der k. k. Naturalien Sammlung zu Wien. Bécs, s. n., 1793. XVI, 174 p. $8^{\circ}-\mathrm{B}$

182.) SulzeR, Johann Georg: A természet szépségéről való beszélgetések (ford. Sófalvi, József). Kolozsvár, Ref. Koll., 1778. 210 p. $8^{\circ}-\mathrm{B}$

183.) SZENT-GyÖrgYi, József: A legnevezetesebb természeti dolgok esméreti (I). Debrecen, Szigethy, 1803. XXXII, 330 fol., [17] fol., 19 t. $8^{\circ}-\mathrm{H}$

184.) SzentivÁNYI, Márton: Curiosiora et selectiora variarum scientiarum miscellanea. Nagyszombat, Typis Academicis, 1702.3 köt. $8^{\circ}-\mathrm{BN}$

185.) Szigeti, Gyula: Méhész könyv. Nagyenyed, s. n., 1763. [1], 46, [11] p. $8^{\circ}-\mathrm{H}$

186.) TAM, Franz Joseph von: Vierfaches Kleeblatt : Hilfsmittel für Horn-, Schaf-, Pferd- und Federvieh. Bécs \& Prága, Trattner, 1764. 605 p., 2 t. $8^{\circ}-\mathrm{BN}$

187.) TeSSEDIK, Sámuel: A paraszt ember Magyar Országban, Engel, Pécs, 1786. [2], 508 p., 1 t. $8^{\circ}-$ $\mathrm{BN}$

188.) TolnAy, Sándor: A lovak külső szép, vagy rút termetek s hibái meg-esméréséröl, és azoknak belső, s külső betegségeik orvoslásáról. Buda, Magyar Királyi Univerzitás, 1816. [5] fol., 218 p., 1 t. $8^{\circ}-\mathrm{B}$

189.) TolnAY, Sándor: Oktatás a marha dögnek megelözéséről és orvoslásáról. Buda, Magyar Királyi Univerzitás, $1816.8^{\circ}-\mathrm{B}$

190.) TURÓcZy László: Ungaria suis cum regibus compendio data. Nagyszombat, Typis Academicis, 1729. 245, [5] p. $8^{\circ}-\mathrm{B}$

191.) TURÓCZY, László: Ungaria suis cum regibus compendio data. Nagyszombat, Typis Academicis, 1768. VIII, 631 p. $8^{\circ}-\mathrm{BN}$

192.) VALENTINI, Michael Bernhard: Amphitheatrum zootomicum. Frankfurt, Zunner \& Jung, 1720. $[21], 114,[5]$ p. $2^{\circ}-\mathrm{B}$

193.) VAlerius, Cornelius: Physicae, seu de naturae philosophia institutio. Antwerpen, Moretus, 1593. 92, [2] p., 1 t. $8^{\circ}-\mathrm{B}$

194.) WeIGEL, Johann Christoph: Deutliche Abbildung einer wohlbestellten Reitschule. s. 1., s. n., s. a. $-\mathrm{H}$

195.) WeRnER, Abraham Gottlob: Von den äusserlichen Kennzeichen der Fossilien. Bécs, Trattner, 1785. 237, [1] p. $8^{\circ}-\mathrm{B}$

196.) WiLHELM, Gottlieb Tobias: Unterhaltungen aus der Naturgeschichte. Bécs, Pichler, 1808-13. 12 köt. $8^{\circ}-\mathrm{BN}$ 
197.) WINTER, Georg Simon: Hippiater expertus, seu medicina equorum absolutissima, tribus libris comprehensa. Nürnberg, Endter, 1678. [15], 490, [9] p. $2^{\circ}-\mathrm{B}$

198.) WINTER, Georg Simon: Tractatio nova et auctior de re equaria, complectens partes tres = Neuer und vermehrter Tractat von der Stuterey, oder Tohlen-Zucht, in drey Haupt-Theile unterschieden. Nürnberg, Endter, 1703. [22], 223 p. $2^{\circ}-\mathrm{B}$

199.) Wolfart, Peter: Historiae naturalis Hassiae Inferioris pars prima / Der Natur-Geschichte Nieder-Fürstenthums Hessen. Cassel, Harmes, 1719. 52 p., 25 t. $2^{\circ}-\mathrm{B}$

200.) WolfF, Christian: Allerhand nützliche Versuche, dadurch zu genauer Erkäntniss der Natur und Kunst der Weg gebähnet wird, denen Liebhabern der Wahrheit mitgetheilet. Halle, Renger, 1727. [14], 599, [9] p., 17 t. $8^{\circ}-\mathrm{BN}$

201.) WolfF, Christian: Vernünfftige Gedancken von dem Gebrauche der Theile in Menschen, Thieren und Pflanzen. Frankfurt \& Lipcse, Renger, 1730. 746 p. $8^{\circ}-\mathrm{B}$

202.) WuRFFBAIN, Johann Paul: Salamandrologia. Nürnberg, Scheurer \& Spörlin, 1683. [6], 133, [17] p, 4 t. $4^{\circ}-\mathrm{B}$

203.) ZeHENTNER, Joseph Christoph: Gründliche Abhandlung der Kunst, Pferde zu kennen. Frankfurt \& Lipcse, Straus, 1775. [19] fol., 344 S., [5] fol., 6 t. $8^{\circ}-\mathrm{BN}$

204.) Szerző nélkül: Der nach medicinischen Lehrsätzen sicher und gewiss curirende Pferdearzt. Lipcse, Gessner, 1752. [10], 280, [4] p. $8^{\circ}-\mathrm{BN}$

205.) Szerző nélkül: Wohlbewährte Fischgeheimnisse oder, Deutlichen Unterricht der grossen Nutzbarkeit der Fischerey. Nürnberg, Bauer, 1758. [16], 288, [12] p. $8^{\circ}-\mathrm{B}$

206.) Szerzö nélkül: Hinlängliche Anleitung zur Seidenzucht und zuverlässige Anweisung. Ulm, Bartholomäi, 1767. [8], 68 p. 1 t. $8^{\circ}-\mathrm{BN}$

207.) Szerző nélkül: Anfangsgründe der Naturgeschichte. Frankfurt \& Lipcse s. n., 1777. 113, [23] p. $8^{\circ}-\mathrm{H}$

208.) Szerző nélkül: Kurze Natur-Geschichte des Thier-Reichs. Nürnberg, Zehe, 1789. 112 p. $8^{\circ}-\mathrm{B}$

209.) Szerző nélkül: Ornithologie abrégée de la France. Neuwied sur le Rhin, Société Typographique, 1794. 31, [1] p. 133 t. $4^{\circ}-\mathrm{B}$

210.) Szerző nélkül: Gründlicher Unterricht in der Taubenzucht. Berlin, Maurer, 1800. [4], 43, [1] p. $8^{\circ}-\mathrm{BN}$

211.) Szerző nélkül: Von den Mitteln wider verschiedene den Menschen, Thieren und Erdfrüchten theils beschwerliche, theils schädliche Insekten und andere Thiere. Graz, Kienreich, 1801. [3] fol., $204 \mathrm{p}$, [1] fol. $8^{\circ}-\mathrm{B}$ 


\title{
Zoological books of the founding book collection of the Library and Information Centre of Hungarian Academy of Sciences
}

\author{
ÁGNES SALLAI ${ }^{*}$ \& ÁDÁM SZABÓ ${ }^{2}$ \\ ${ }^{1}$ Library and Information Centre of Hungarian Academy of Sciences, Department of Library Systems \& \\ Technology, H-1051 Budapest, Arany János u. 1.*E-mail: sallai.agnes@konyvtar.mta.hu \\ ${ }^{2}$ Library and Information Centre of Hungarian Academy of Sciences, Department of Manuscripts \& Rare Books, \\ H-1051 Budapest, MTA Palota, Széchenyi István tér 9. E-mail: szabo.adam@ konyvtar.mta.hu
}

ÁLLATTANI KÖZLEMÉNYEK (2020) 105(1-2): 3-28.

\begin{abstract}
Even if books on miscellaneous topics, mainly those broadly related to agriculture, are taken into consideration, the founding book collection of the Library and Information Centre of the Hungarian Academy of Sciences contains a relatively small number of zoological titles. Of the 30,000 volumes donated by Count JÓZSEF TELEKI on behalf of his family to the Academy, only 406 titles are related to zoology proper and only 47 of these can be regarded in one way or another as Hungarica. However, the small number of these books is not to be taken as an indication of the lack of interest in zoology on the part of the TeLEKIs but rather as a reflection of the age itself. In spite of the spectacular development of the natural sciences in the course of the 18th and early 19th century, the importance they were to gain in the 20th century was not yet achieved. Moreover, and mainly due to the peculiar political-constitutional conditions of Hungary, other disciplines attracted more attention in that period. In view of this, the book collecting efforts of the TeLEKIs deserve our praise and recognition: in addition to a number of titles by foreign authors, still renowned today, they aimed to purchase almost every book that was published on zoology in contemporary Hungary.
\end{abstract}

Keywords: TELEKI family, natural history, bibliography.

Accepted: 26.09.2019

Published online: 22.10 .2019 